\title{
¿Utopía o realidad? Reflexiones en torno al arte religioso de la primera mitad del siglo XX
}

\author{
José Javier Azanza López \\ Ignacio Jesús Unricelqui Pacho
}

Durante la primera mitad del siglo XX los artistas van a experimentar las consecuencias de la progresiva desunión entre arte y religión. Es en este momento cuando la Iglesia y un importante sector de la crítica plantearon algunas de las posibles soluciones: por un lado se insistió en la educación del clero y de los fieles, buscando igualmente la recuperación del buen gusto y el rechazo a las excentricidades que las tendencias más modernas propusieron; рот otro, se inició un profundo debate acercia de la necesidad de que el artista siguiera o no el sendero de la fe para abordar una obra religiosa.

Along first half on XX century, disunion between Art and Christian Religion and its consequences were being felt heavily upon artists. In this situation, Catholic Church and an important group of the critics carried out some of possible solutions. On one hand, the education of clergy and public ought to be accompanied by regain of good taste and rebound of supposed "eccentricities" connected with contemporary artistic movements. On the other hand, the position of artists face to sacred work and necessity of Faith for perfecting its execution was extensivively and deeply discussed.

\section{INTRODUCCIÓN}

El Dios de la iglesia y de los pequeños burgueses ha muerto. Esta sentencia de la muerte de Dios proclamada por Nietzsche plantea uno de los grandes interrogantes del arte del siglo XX, como es la posibilidad de tratar de manera convincente la temática religiosa en la modernidad, o hasta qué punto en un mundo secularizado aún es posible hablar de Dios y de los contenidos cristianos y trasladarlos al lienzo. La inseguridad en la propia existencia de Dios, así como en la manera de representarlo, motivaron un acusado deterioro de las relaciones arte-religión en la

AZANZA LÓPEZ, José Javier y URRICELQUI PACHO, Ignacio: “ ¿Utopía o realidad? Reflexiones en torno al arte religioso de la primera mitad del siglo XX", en Boletín de Arte $\mathrm{n}^{\circ}$ 23, Universidad de Málaga, 2002, págs. 405-437. 
primera mitad de siglo y la consiguiente disminución de los artistas de renombre que se dedicaron a trabajar para la Iglesia. A lo largo de este período, tanto Pío $X$ como sus sucesores en la silla apostólica intentaron por todos los medios volver el arte a la iglesia con varios documentos pontificios. Pero en el camino surgen numerosos interrogantes: ¿cómo se ha de lograr la reconciliación: siguiendo el viejo estilo de las creaciones académicas, o por el contrario, dejando a los innovadores del arte, sin atención a sus convicciones personales, trabajar libremente en el campo religioso? ¿Resulta la fe condición esencial para iluminar el arte? ¿Cabe el vanguardismo religioso en arte? ¿Es sagrado el arte abstracto? ¿Qué dirán los fieles, cómo reaccionarán ante ese "nuevo estilo"? 1

\section{LA DECADENCIA DEL ARTE RELIGIOSO Y SUS CAUSAS}

Dedicarse a la pintura religiosa en estos tiempos que corremos parece, a primera vista, desatino. Tal género pictórico se evoca ya como algo muy lejano que fue gustado por generaciones que no hemos conocido. Por eso cuando algún artista se presenta exhibiendo cuadros de tema religioso le miramos como venido de otro planeta o cual supervivencia extraña de épocas muy pretéritas ${ }^{2}$. Esta afirmación realizada en 1925 por el crítico Antonio Méndez Casal con motivo de la exposición en el Círculo de Bellas Artes de Madrid del pintor Ramón Pulido, pone de manifiesto la clara conciencia de crisis por la que atraviesa el arte religioso en la primera mitad del siglo XX.

Preguntarse por las causas de esta situación obliga a volver la vista atrás. En opinión de Fernando Jiménez Placer, colaborador habitual de El Debate, el arte religioso ha venido contaminándose desde el Renacimiento con una inspiración hibrida de paganismo ${ }^{3}$, de manera que se fue perdiendo la sinceridad, la honradez del artesano -más que artista- medieval, que ofrecía a Dios lo mejor de su producción. De la misma opinión son pintores como Federico de Madrazo, para quien a partir del siglo XVI los artistas descuidan el verdadero y último fin del arte

\footnotetext{
${ }^{1}$ Orientadores al respecto resultan los trabajos de TiLLICH, P, Religión y artes plásticas, 1955; OCHSÉ, M., El arte sagrado de nuestra época, Andorra, Ed. Casal i Vall, 1960; PÉREZ GU'TIÉRREZ, F, La indignidad en el arte sagrado, Madrid, Ed. Guadarrama, 1961; ARENAS, Fr. A., Concilio: arte sacro moderno, Villava, Ed. OPE, 1964; y PLAZAOI.A, J., Historia y sentido del arte cristiano, Madrid, Biblioteca de Autores Cristianos, 1996.

2 "Exposiciones recientes de obras de artistas muy notables en Madrid", $A B C$, Número Extraordinario, Julio de 1925.

" JMÉ́NEZ PLACER, F, "La nueva iglesia de San Pedro, en Chaillot", E1 Debate, 16 de agosto de 1935. En parecidos términos se expresan B. Jiménez Duque y Rafael Calvo Serer. CABRERA GARCIAA, M. I., Tradición y Vanguardia en el pensamicnto artistico español (1939-1959), Granada, Universidad de Granada, 1998, págs. 68 y 91-93.

${ }^{4}$ Significa Madrazo que desde la mitad del siglo XVI acá no se han representado tan bien, tan convenientemente, los asuntos religiosos como se representaban antes". HERRERO GARCİA, M., "Un discurso de Madrazo sobre el arte religioso", Arte Español, Tomo XIV, 1942, págs. 13-20.
} 
cristiano $^{4}$; Georges Rouault, quien considera el clasicismo como algo artificial, en tanto que es en los artistas medievales y en la obra tardía de Rembrandt en quienes encuentra esa espiritualidad profunda y sincera que quiere transmitir a sus obras; Gino Severini, a cuyo juicio cuando el cuadro de caballete comenzó a disfrutar de una vida autónoma y a perder toda finalidad práctica determinada, se engendró la decadencia del espíritu religioso, en alusión al plasticismo espléndido, pero indiferente, del Renacimiento; y Emil Nolde, quien no duda en criticar las pinturas superficiales de Rafael, tan apropiadas para el ambiente de dogos y papas, pero incapaces de alcanzar el verdadero sentimiento religioso ${ }^{5}$.

Mas el espíritu laico que animaba el Renacimiento se acentúa en el siglo XIX, cuando las corrientes filosóficas de la época, que pretendian explicar como algo puramente mecánico la vida del Universo, provocaron un enfriamiento de la fe que se dejó sentir iguaimente en el arte; los encargos de obras de asunto religioso disminuyeron y los artistas decidieron emplear su creatividad en otros géneros, encontrando su principal clientela en la burguesía y el Estado en detrimento de la Iglesia, que ya no se encontraba en condiciones de jugar el papel de mecenazgo que desempeñó en siglos anteriores ${ }^{6}$. Es ahora cuando sobreviene la verdadera decadencia del arte religioso, que se explica a través de la crisis de fe que afecta a la sociedad contemporánea?. Tal y como afirmaba en 1919 el escritor francés Paul Claudel, todas las causas de la decadencia del arte sacro pueden resumirse en una sola: es el divorcio, cuya consumación se produjo en la pasada centuria, entre las proposiciones de la Fe y esas potencias de la imaginación y la sensibilidad que son eminentemente las del artista ${ }^{8}$.

El siglo de la ciencia y la técnica no resultaba el marco más idóneo para que los artistas fueran capaces de infundir auténtico fervor religioso a sus obras, que en muchos casos acabaron por perder su identidad para convertirse en un subgénero

\footnotetext{
${ }^{5}$ A juicio de Gino Severini, los artistas italianos del Renacimiento y del Barroco carecen del reflejo sobrenatural, de aquella iluminación del más allá que los humildes artistas de la antigüedad sabían infundir a sus personajes, que eran verdaderamente divinos, a pesar de estar construidos plásticamente de acuerdo con las proporciones humanas y modelados conforne a lo humano. En la misma línea de crítica a la pintura italiana del Renacimiento se manifiesta Emil Nolde cuando afirma que este pintor prefiere con mucho las santas madonas alemanas, revestidas con el espíritu de Grünewald y de otros, a las pinturas latinas, superficialmente presentadas, de Rafael, tan apropiadas para el ambiente de dogos y papas". CONSIGLIO, C., "Ideas sobre un arte religioso de un pintor italiano", Revista de Ideas Estéticas, n 5 , 1944, págs. 117-118. CHIPP, H. B., Teorfas del arte contemporáneo. Fuentes artísticas y opiniones críticas, Madrid, Ediciones Akal, 1995, págs. 168-169.

${ }^{6}$ Un exhaustivo análisis de la decadencia del arte religioso en el siglo XIX y sus causas es realizado por ÁLVAREZ LOPERA, J., "La crisis de la pintura religiosa en el siglo XIX", Cuadernos de Arte e Iconograffa, Tomo I, no 1 , 1988, págs. 81.-120.

${ }^{7}$ PÉREZ SOLÍs, O., "Fe y cultura religiosas", El Debate, 27 de noviembre de 1932.

${ }^{8}$ CLAUDEL, P., "Lettre a Alexandre Cingria sur les causes de la décadence de l'art sacré", Positions et propositions, T. II, París, Gallimard, 1934, pág. 223.
} 
de la pintura de historia: el pintor, antes de dar comienzo a un cuadro de asunto religioso, preparaba cuidadosamente la guardarropía, se lamentan los críticos. En torno a la década de los setenta, la pintura de historia domina por completo el panorama europeo, produciendo grandes lienzos declamatorios de marcado carácter teatral en los que da igual que los protagonistas sean reyes o bandidos, guerreros o santos; es decir, las escenas bíblicas, evangélicas o de vidas de santos reciben un tratamiento como pintura llana y lisamente de historia (F/G. 1). De este modo, los pintores tendieron a realizar cuadros de crónica o historia religiosa, más que cuadros religiosos en sentido estricto ${ }^{9}$. Toda esta grandilocuencia resta a las obras emoción y sentimiento, imprescindibles en el género religioso: $y$ si bien ciertas obras pueden interesar, aunque no emocionen, cuando esta cualidad falta en el arte religioso no queda ante los ojos otra cosa que una serie de maniquíes más o menos bien hechos ${ }^{10}$. La falta de emoción, de autenticidad en definitiva, se convierte por tanto en el gran problema del arte religioso, destinado a Museos y Exposiciones y anteponiendo los valores estéticos a los devocionales"11.

Pero la crisis del arte religioso es mal que tiene raíces más profundas: no es solamente decadencia del sentimiento religioso del momento, sino también del sentido estético, corrupción del buen gusto artístico en relación con la Iglesia; y esta situación no se observa sólo en el terreno religioso, sino que implica a todos los ámbitos de la creatividad artística. Dicho de otro modo, es el arte en sí mismo el que está en crisis $^{12}$. Antonio Méndez, con motivo del VI Salón de Otoño en Madrid

\footnotetext{
${ }^{9}$ Un interesante planteamiento sobre pintura de historia y religión es realizado por Reyero, a cuyo juicio la pintura de historia ni tiene ningún objetivo de tipo religioso, entendido con sentido devocional, ni encierra un mensaje, siquiera secundario, de carácter espiritual, porque en eso se diferencia del género propiamente religioso, aunque a veces -en especial si se trata de episodios de la vida de santos- se confunda éste con lo histórico. REYERO, C., La pintura de historia en España, Madrid, Cátedra, 1989, págs. 144-149.

in Deberíamos hacer no obstante una matización sobre la diferencia que debe percibirse al hablar de una obra de arte con finalidad religiosa, y otra de temática religiosa. Ya Pedro de Madrazo diferenciaba a propósito de los cuadros que presentó Esquivel a la exposición de la Academia de 1842 entre "cuadros de asuntos místicos" y de "historia sagrada", si bien abogaba por el tratamiento idealista de todos ellos. En la clasificación de los géneros pictóricos que establecía Tubino en 1871 hablaba de cuadros de historia (representación de acaecimientos de la vida civil o religiosa de que los historiadores han escrito) y cuadros litúrgicos (todos los que tienen por objeto los misterios o tipos convencionales de la religión). Y en su crítica a la Exposición Nacional de 1897, Jacinto Octavio Picón se planteaba la misma cuestión, manifestando la posibilidad de sentir y pintar algunos asuntos religiosos a través de su consideración como temática histórica, dejando de Iado la finalidad religiosa que caracteriza a la obra sacra, ÁLVAREZ LOPERA, J., op. cit, pág. 95. OCTAVIO PICÓN, J., "La Exposición de Bellas Artes", La Itustración Española y Americana, año XLI, $n^{\circ}$ XXI, Madrid, 8 de junio de 1897, pág. 343.

${ }^{11}$ Así lo constata ÁLVAREZ LOPERA, J., op. cit, pág. 82. Véase también CAPARRÓs MASEGOSA, L., Prerrafaelismo, simbolismo y decadentismo en la pintura española de fin de siglo, Granada, Universidad de Granada, págs. 93-95.

12 "El arte dejó de ser una actividad social para convertirse en un campo aparte que, salvo raras excepciones, no podfa reflejar el pensamiento de una sociedad en la que estaba como
} 


\section{Q $=$ ¿Utopía o realidad? Reflexiones en tomo al arte...}

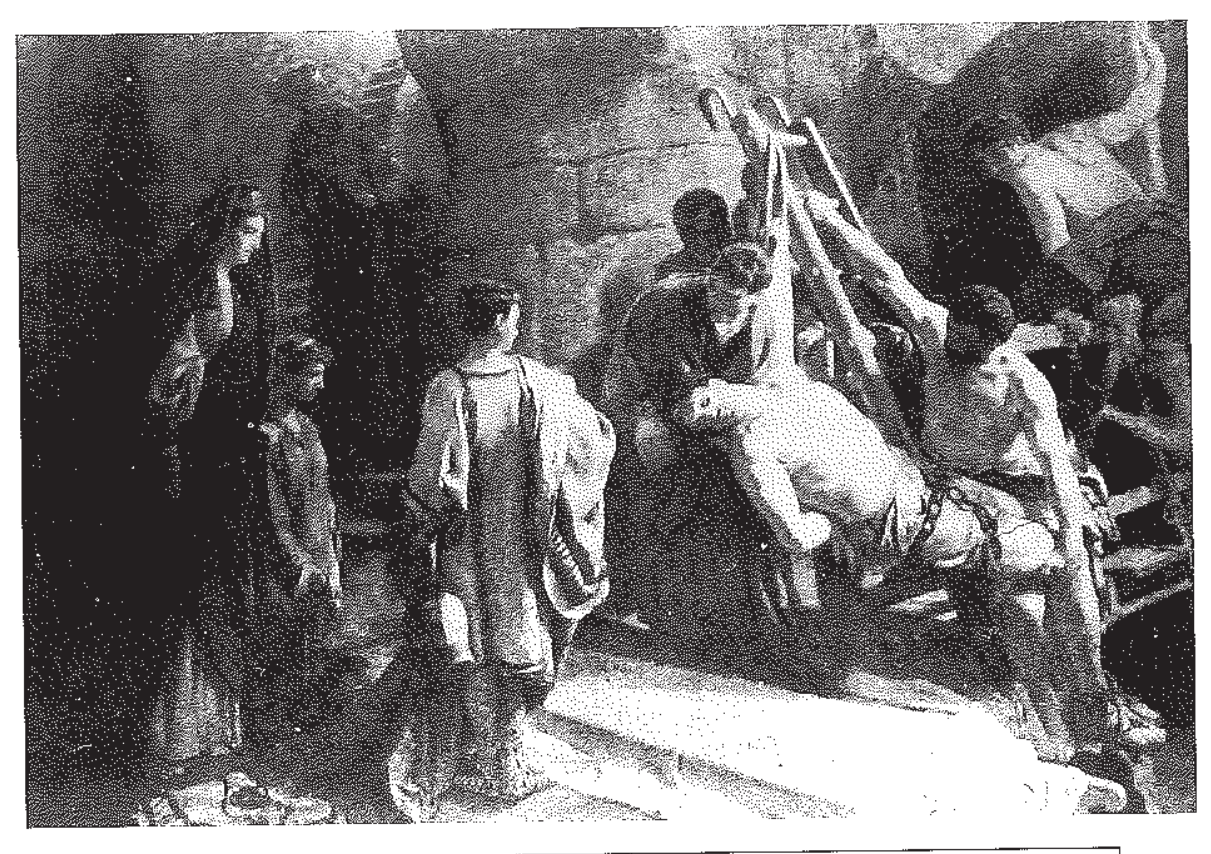

1. Alejandro Ferrant. El Entierro de San Sebastián. 1877. Casón del Buen Retiro

celebrado en 1925, realiza unas interesantes reflexiones al respecto: "Quien se interne por los laberintos de una gran parte de la Estética ultramoderna llegará a dudar en algún momento si esta disciplina tiene algo que ver con el Arte... Una multitud de voces destempladas pidiendo radicales y diarias renovaciones estéticas, ejerce en Europa una dura coacción que acobarda a los artistas, obligándoles a torcer el rumbo. "Seamos modernos, eso ya pasó. Hay que hacer un arte identificado con el sentir actual", expresiones que se oyen a todas horas, sin que nadie precise cuáles son esas inquietudes ni ese sentir de hoy. Ya voy creyendo que lo único que se percibe claramente es un desentrenado arrivismo. Mientras... el oficio se va perdiendo, y un día no lejano puede llegar en que se haya olvidado todo y sea urgente comenzar de nuevo ${ }^{13}$.

enquistado, pero sin contacto íntimo con ella. Dejó de ser instrumento, modo de expresión de su sentir común, para no ser reflejo más que de movimientos caprichosos, tendencias pasajeras, modas rápidas, extravagancias o gritos histéricos de exaltados, tan pronto lanzados como perdidos, sin que la mayor parte fueran recogidos ni influyeran de un modo visible en el resto de la sociedad". DE LA CUEVA, J., "Las Órdenes religiosas inspiran y protegen el tesoro pictórico nacional", E1 Debate, 28 de febrero de 1934.

${ }^{13}$ MÉNDEZ CASAL, A., "Algunas impresiones del interesante VI Salón de Otoño en Madrid", $A B C, 25$ de octubre de 1925. EI juicio del crítico coincide con el que en 1919 emitía Giorgio de Chitico en su escrito titulado "El regreso al oficio", donde podemos leer lo siguiente: iVolver al oficiol No será fácil, hace falta tiempo y esfuerzo. Faltan escuelas y maestros, o quizás los hay, 
9. José Javier Azanza e Ignacio Urricelqui

También el bilbaíno Juan de la Encina, con su particular claridad y buen estilo, señalaba en 1934 que la raíz profunda de la crisis artística que padecía su época se encontraba en lo espiritual y se traducía en la faita de inspiración que afectaba a los artistas del momento: Quien contemple siquiera panorámicamente los movimientos artísticos en lo que va de siglo, advertirá que los artistas buscan a la desesperada un algo, una inspiración que no poseen. Ésta sí que es la verdadera, la inequívoca crisis artistica de nuestro tiempo; y añade: si se contempla cómo esos millares de artistas bucean denodadamente en las profundidades de sus espiritus en querencia de una originalidad y vuelven a la superficie del mismo casi siempre con las manos vacías, entonces si que se comprende toda la hondura de nuestra crisis artistica ${ }^{14}$. Abundando en el por qué de la crisis artística, concluye que ésta no es más que una de las facetas de otra crisis más profunda, la que padece el espíritu contemporáneo, que ha dado como resultado la desmoralización profesional, el olvido del buen oficio, de la obra pulcra, primorosamente realizada, llevando en su defecto a esas clases de invenciones en virtud de las cuales se atribuye a las artes un cierto linaje de pensamientos esotéricos, que en realidad no expresan otra cosa que el vacío o la desolación de los espiritus. Esta situación ha provocado que la sociedad contemporánea haya caido en la desidia y el abandono, dejando de lado las grandes formas artísticas, que ya no son consideradas como necesarias para el espiritu y la vida's. De igual forma Isaac $\mathrm{M}^{\mathrm{a}}$ Toribio, al estudiar la escuela benedictina alemana de Beuron, alude a la extrema degeneración a que ha llegado el gusto artístico, arrastrado por el realismo sensual de una filosofía materialista. El gran arte monumental y decorativo, sobre todo, se halla perdido hace tiempo, y el templo cristiano adolece también de esta decadencia; es menester restaurar ese gran arte ${ }^{16}$.

\footnotetext{
pero resignadas y resignados a las alegrias coloristas que desde hace casi medio siglo se enseñorean de Europa... Volviendo al oficio, nuestros pintores deberán estar sobremanera atentos al perfeccionamiento de los medios: lienzos, colores, pinceles, aceites, bamices deberán ser escogidos entre los de mejor calidad... Convendría que los pintores recuperasen la óptima costumbre de prepararse personalmente los lienzos y los colores. DE CHIRICO, G., El mecanismo del pensamiento, 'Turín, Einaudi, 1985, págs. 95-99.

14 JUAN DE LA ENCINA, "La grave crisis actual", E1 Sol, 20 de octubre de 1934; véase también "La crisis del arte", El Sol, 12 de noviembre de 1931.

t5 La desmoralización de la sociedad del momento es uno đe los temas centrales que analiza Ortega y Gasset en su obra La rebelión de las masas, publicada por primera vez en 1930. ORTEGA Y GASSET, J., La rebelión de las masas. Edición, introducción y notas de Thomas
Mermall, Madrid, Castalia, 1998. ${ }^{16}$ TORIBIO, I. M., "La admirable escuela benedictina alemana de Beuron", $A B C$, febrero de
1925.
} 
Siendo conscientes de la crisis y apuntadas algunas de sus causas, existe el firme convencimiento de que el arte religioso necesita una regeneración, retomar el rumbo perdido. Pero, ¿cuáles son las claves de esta renovación?

En primer fugar, resulta imprescindible la correcta educación artística del clero y de los fieles que permita desterrar todos los atropellos que se están cometiendo en este terreno. En una recepción ofrecida por Pío XII en 1950 a 300 artistas y autoridades en arte procedentes de 23 países, la mayoría de los delegados reclamaron la necesidad de modernizar la cultura artística del clero, corrompida en ocasiones por la belleza artificial de las imágenes de catálogo ${ }^{17}$. En palabras de algunos de ellos, las casas proveedoras de las iglesias han destruido el buen paladar de los fieles con esos catálogos de vírgenes, en que prodigan sus malas producciones. Es necesario que todos ayudemos al artista cristiano a terminar con el escándalo de esa porquería de imágenes que hay en muchas iglesias ${ }^{\text {t8}}$.

Si hay un aspecto en el que existe rotunda unanimidad a la hora de enjuiciar el arte religioso es en la crítica al denominado estilo "Saint-Sulpice", tan admirado por un pueblo carente ya de sensibilidad religiosa y artística, cuyos partidarios son denostados como los amigos de las imágenes en cartón piedra, que han sembrado las iglesias de amaneradas e insípidas esculturas, que artísticamente no inspiran placer y religiosamente no conmueven el alma en oración $n^{19}$. Se trata de esas imágenes de escayola que no salen de un talier escuitórico sino de una fábrica donde son producidas en serie (FiG. 2). La crítica artística emprendió una auténtica "cruzada" para tratar de erradicar esta moda que arraigó con fuerza en las primeras décadas de siglo, ya que veía en ella un doble peligro: la proliferación de estas pseudoimágenes no sólo impedía que los verdaderos escultores pudiesen desarrollar su oficio en el terreno religioso, sino que además la escasa formación artística de buena parte del clero motivó la desaparición de numerosas obras de

\footnotetext{
${ }_{17}$ Sobre la importancia de los catálogos comerciales franceses del siglo XIX, aunque de naturaleza diferente a la que aquí nos ocupa, véase MONTOYA BELEÑA, S., "Catálogos comerciales franceses del siglo XIX en Valencia: el álbum de la Casa Thiriot y el álbum de la Casa Garnier", Actas del XI Congreso del CEHA. El Mediterráneo y el arte español, Valencia, Generalitat Valenciana y Ministerio de Educación y Cultura, 1998, págs. 387-393. Para el caso español puede consultarse PITARCH, A. J. y DALMASES, N., Arte e industria en España, 17741907, Barcelona, Blume, 1982.

18 "El Papa habla de arte". El Pensamiento Navarro. 23 de Septiembre de 1950, pág. 6.

19 Sobre el comercio de objetos religiosos y la fabricación de esculturas de terracota en los talleres del barrio parisino de Saint-Suipice, así como sobre diversas consideraciones acerca de la expresión "arte sansulpiciano", véase ALBARIC, M., "Le commerce des objets religieux dans le quartier Saint-Sulpice", en De pierre et de coeur. L'église Saint-Sulpice. 350 ans d'histoire, París, Les Éditions du Cerf, 1996, págs. 131-158.
} 


Q3arrirvios _osé Javier Azanza e Ignacio Urricelqui

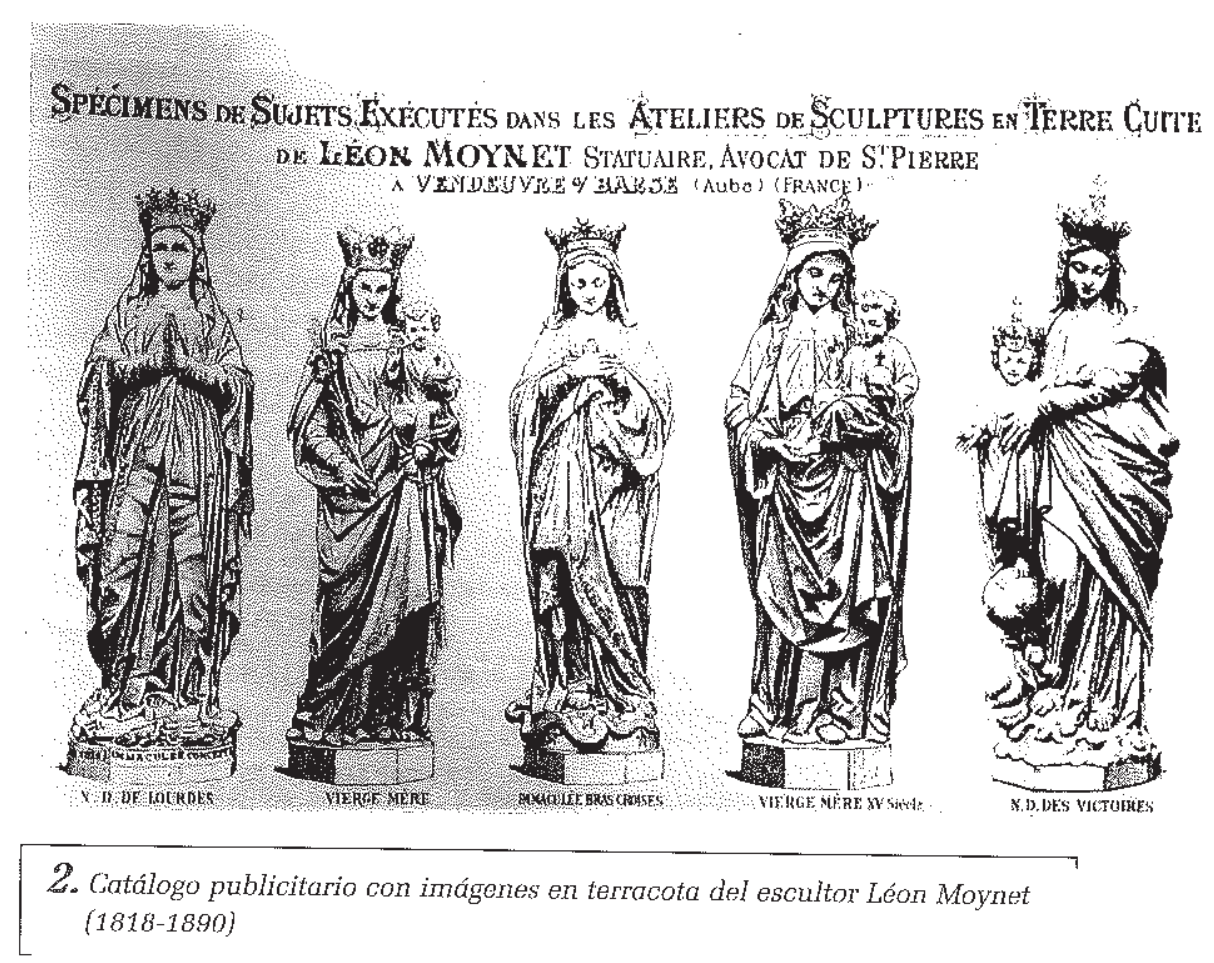

incuestionable valor para dejar paso a esculturas inexpresivas e insulsas. Es más, el carácter convencional, exangüe y trivial de estas imágenes religiosas no era sino el fiel reflejo de la fealdad moral de la sociedad de la época. En su obra Les foules de Lourdes, publicada en París en 1907, el escritor converso K. H. Huysmans significaba que las imágenes de la Virgen que propagaba el comercio artístico de la época eran una revancha del demonio contra el triunfo de María Inmaculada $a^{20}$. Pocos años más tarde, el pintor suizo Alejandro Cingria afirmaba en su obra La Décadence de l'art sacré que la Iglesia carecía de arte sagrado desde hacía más de un siglo². Y Paul Claudel coincidía con los anteriores al constatar que este pseudo-arte era un espejo de los defectos y pecados del ser humano: debilidad, indigencia y timidez de

\footnotetext{
${ }^{20}$ Evidentemente en ningún lugar, en ningún pals, en ninguna época, ha habido tal audacia en la exhibición de tan sacrilegos horrores; $y$ si se piensa que han sido elaborados expresamente para Lourdes, fabricados ex profeso para Nuestra Señora, se puede deducir de ese espectáculo alguna enseñanza. A no dudarlo, tales atentados no pueden atribuirse más que a bufonadas vindicativas del demonio. HUYSMANS, K. H., "Sobre la fealdad de las imágenes de la Virgen", en Les foules de Lourdes, París, 1907.

${ }^{21}$ CINGRIA, A., La Décadence de l'art sacré, Laussane, Cahiers Vaudois, 1917. Pese a su brevedad y omisiones, la obra de Cingria constituye la primera confrontación seria con el problema del arte religioso.
} 
la fe y del sentimiento, sequedad del corazón, asco de lo sobrenatural, predominio de las convenciones y de las fórmulas, exageración de las prácticas individuales y desordenadas, lujo mundano, avaricia, jactancia, chabacanería, hinchazón y y fariseísmo ${ }^{22}$.

También la crítica española dictó su sentencia al respecto. Juan de la Encina se refiere a este arte de bazar, decrépito en grado superlativo, del que todo espíritu religioso ha huido y carente de la nobleza necesaria para encarnar unos valores religiosos dignos y robustos ${ }^{23}$. Dura es asimismo la opinión de Jiménez Placer, quien considera a este tipo de arte imaginería de acarreo, imitación vacía de fórmulas tradicionales, servida por artistas mediocres en obras industriales ${ }^{24}$ (FIG. 3). Pero sin duda uno de los que más se distinguió en esta lucha fue Antonio Méndez Casal, quien desde las páginas de crítica de arte de $A B C$ y de la revista Blanco y Negro censuró una y otra vez en la década de los años veinte las imágenes de escayola, defendiendo por él contrario la labor de la talla, el secreto de infundir alma a la madera realizada por imagineros como Francisco Asorey, José Capuz, Mariano Benlliure, Victorio Macho, Aniceto Marinas, José Clará o Quintín de Torre.

Numerosos son los artículos de Méndez Casal en los que manifiesta su pesar por esta ola de mal gusto que ha invadido los templos. En uno de los más tempranos, firmado en 1926, asegura que los procedimientos mecánicos modernos de oficio han perjudicado grandemente a la Escultura... El viejo estudio de escultor se convirtió en taller, y éste, en muchos casos, descendió hasta disolverse en gran nave de fabricación en serie. El caso del escultor que paso a paso cincela un mármol hasta la conclusión, va resultando insólito. Por este motivo alaba un Crucificado de bronce ejecutado por Victorio Macho ( $F I_{\text {G. }}$ 4) con destino a una de las capillas de la iglesia parroquial de Los Corrales de Buełna, en Santander: Es caso que merece cordial admiración, en estos tiempos de Cristos de cartón-piedra hechos en serie, con la misma técnica de la fabricación de galletas. Por esos mundos de Dios abundan como la viruela talleres en activa competencia comercial. Y el que logra dar más barato el metro cúbico de Cristos, es el favorecido ${ }^{25}$. Dos años más tarde el crítico insistía, a propósito de la obra del escultor vasco Quintín de Torre, en la necesidad de que las congregaciones y entidades religiosas de todas clases abandonen esa desdichada afición a la pacotilla de cartón-piedra ejecutada en serie y protejan el arte, tan español, de la imaginería ${ }^{26}$. $Y$ a la misma época corresponde uno de sus artículos más

${ }^{22}$ PLAZAOLA, J., op. cit., pág. 965 y 984. CLAUDEL, P., op. cit., pág. 226.

${ }^{23}$ JUAN DE I.A ENCINA, "Arte medieval", El Sol, 16 de enero de 1934.

${ }^{24}$ JMÉNEZ PLACER, F., "La nuteva iglesia de San Pedro, en Chaillot", art. cit.

${ }_{25}$ MÉNDEZ CASAI, A., "Las recientes exposiciones", Blanco y Negro, nº 1858. Madrid, 26 de diciembre de 1926. Para más información sobre esta imagen, a la que Elías Tormo llegaría a calificar como "el Cristo del siglo XX", véase la obra de BRASAS EGIDO, J. C., Victorio Macho. Vida, arte. obra, Valladolid, 1987, págs. 121-122.

${ }^{26}$ MÉNDEZ CASAL, A., "Varias exposiciones. La Dolorosa de Quintín de Torre", Blanco y Negro, $\mathrm{n}^{\circ}$ 1932. Madrid, 27 de mayo de 1928. 


\section{Imágenes de pasta de madera. Catálogo de Ornamentos de Iglesia. Casa Aranda, Zaragoza}

\section{IMAGENES DE PASTA MADERA}

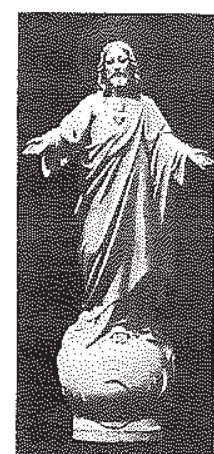

N." on

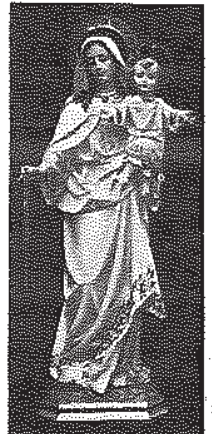

N. 25

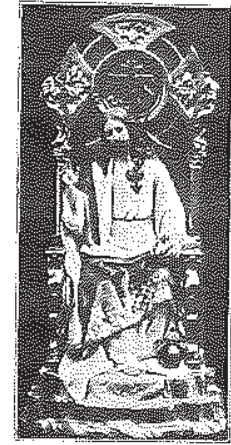

$N=\underline{H}+1$

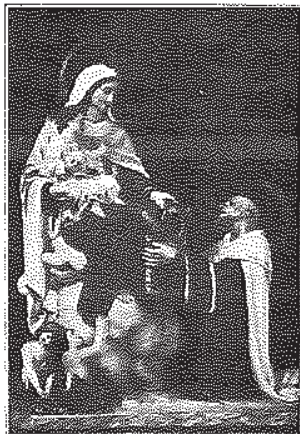

$4+6$

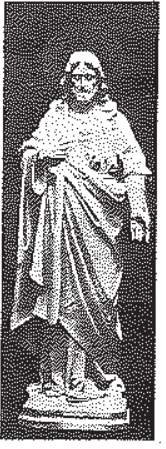

N." 161

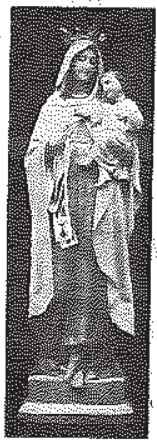

$42: p$

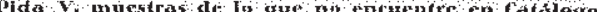

extensos en el que aborda sin rodeos esta cuestión, definiendo esta moda como plaga vergonzosa que viene ya de hace años envileciendo el arte religioso, contra la que viene siendo muy urgente emprender una cruzada eficaz y vigorosa ${ }^{27}$.

Incluso Miguel de Unamuno opinó sobre el particular en una fecha tan temprana como 1914 al escribir en el Heraldo de Cuba sobre el Cristo románico de San Juan de Barbalos: Y entonces, mirando el venerable Cristo románico, di en pensar que hoy llenan nuestros altares, encendiendo el fervor de los devotos, muchas imágenes del Crucificado tan feas o más feas que aquella de San Juan de Barbalos, pero de un feo

${ }^{27}$ MÉNDEZ CASAL, A., "El arte religioso moderno. Su decadencia", Blanco y Negro, $\mathrm{n}^{\circ} 1924$. Madrid, 1 de abril de 1928. 


\section{Q. - ¿Utopia o realidad? Reflexiones en torno al arte...}

1. Victorio Macho. Cristo. 1926. Iglesia parroquial de Los Corrales de Buelna (Santander)

más moderno, de una fealdad que no ha pasado aún de moda ${ }^{28}$. Es muy probable que Unamuno abogase en favor del arte religioso del pasado medieval frente a la nueva moda artística de los Cristos de escayola.

Para desterrar este tipo de imágenes que han invadido los templos deben tomarse medidas como la catalogación del patrimo-

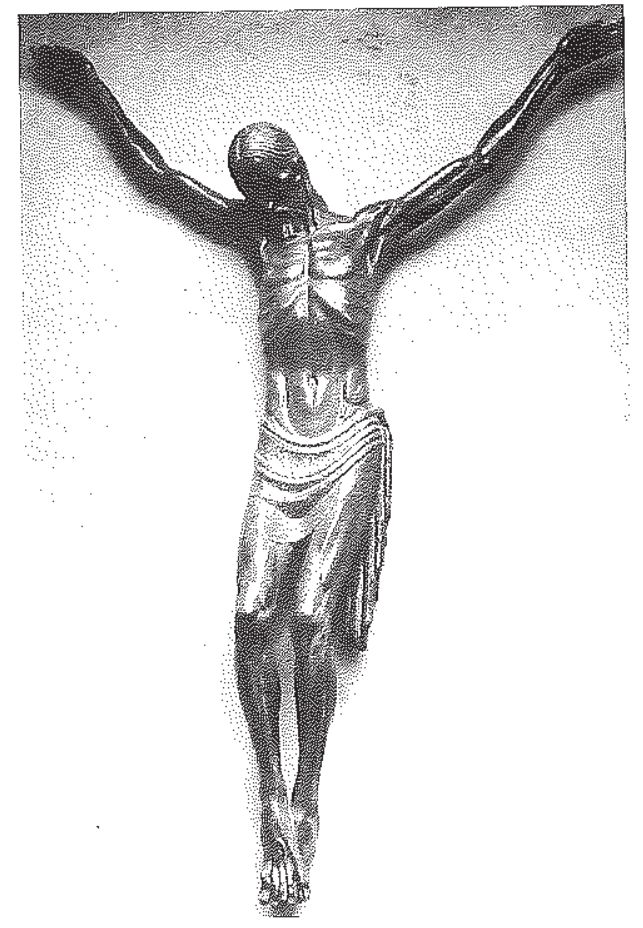
nio artístico de las diócesis, la enseñanza obligatoria de la Historia del Arte en los Seminarios, o la instalación de Museos Diocesanos. Con motivo del Segundo Congreso de Arte Sagrado celebrado en Roma en 1934, el padre Donostia reflexiona sobre la conveniencia de la educación del buen gusto en los seminarios y otros centros, pues adecuándose al mismo muchos templos no verían tantos despropósitos en punto a decoración, mueblaje, música, etc. Cumplidas exactamente y bien las ordenaciones litúrgicas, se respiraria en los templos un buen gusto "inevitable", se sentiria una temperatura agradable para el alma. En cambio, cuando el hombre quiere salirse de este carril o añadir a lo establecido algo de su cosecha... jcuánta tonteria no hace!". Para el padre Donostia, la clave del buen gusto se encuentra en las palabras del pintor francés Maurice Denis, quien se muestra partidario de la educación del clero desde su base en los Seminarios. Dice Denis: Quisiera que en cada Seminario hubiera un poeta, un artista encargado de la precisa función de cultivar el entusiasmo, de exaltar el gusto de la hermosura lírica, la de los Libros Sagrados y la que debieran tener las obras de arte en la iglesia... Quisiera que los seminarios se acostumbrasen a exigir de una vidriera, de una estatua, de una pintura, la misma exaltación que la que encuentran en las magnificencias de la oración litúrgica. No es de gran utilidad que sean capaces

2B "El Cristo de San Juan de Barbalos", Heraldo de Cuba, 6 de julio de 1914, reproducido en UNAMUNO, M. de, En torno a las artes, Madrid, Espasa-Calpe, 1976, págs. 85-91. 
de discutir con un arquitecto acerca de la exactitud de una restauración, del estilo de tal o cual iglesia. Lo que es indispensable es que sepan gustar de la poesía de los Libros Santos para obligar a los artistas a inspirarse en ellos y a vivir en esas alturas. Que estén tan enamorados de la belleza litúrgica que no toleren nada bajo, vulgar, enojoso, en las obras que sirven de ornamentación en la Casa de Dios y de enseñanza al pueblo fiel ${ }^{29}$.

Tan importante como la educación artística del clero será la de los fieles, para que dejen de estar de moda frases como la siguiente: ¿Queréis hacer huir a un católico? Presentadle algo hermoso. El efecto será seguro. Juan de la Encina ya apuntaba como una de las causas de la decadencia artística en general la no muy exquisita educación estética de nuestro público, y especialmente de esa parte del público que se halla en condiciones de hacer encargos a los artistas ${ }^{30}$. El papa Pío XII, a través de la Encíclica Mediator Dei, publicada el 20 de octubre de 1947 , animará a la Iglesia en su labor promotora de iniciativas que proporcionen al puebio un conocimiento más profundo de la Sagrada Liturgia, defendiendo la nobleza de las imágenes. También la Iglesia y el Estado, habituales promotores de las artes, deberían volver a sentirse identificados con el espíritu de mecenazgo artístico que les caracterizó en épocas anteriores, actuando directamente en la materia mediante el encargo de ejecución de obras a los artistas de mayor prestigio, reorientando a su vez el gusto artístico del público ${ }^{31}$. Puestas en práctica estas medidas traerán como consecuencia la negativa a comprar obras absurdas que al no tener demanda dejarán de fabricarse, de igual manera que por falta de demanda los verdaderos artistas dejaron de cultivar el arte religioso ${ }^{32}$.

\footnotetext{
29 "De arte sagrado. Interesante artículo del P. Donosti". La Voz de Navarra. 30 de Noviembre de 1934.

30 JUAN DE LA ENCINA, "Por las exposiciones", España, 22 de febrero de 1917.

${ }^{31}$ A este respecto proponía Juan de la Encina tres grandes áreas de intervención estatal: los museos, capaces de modificar por sí mismos el comportamiento estético del público; la ensefranza artística, sobre todo profesional; y la revitalización del mecenazgo institucional. Considera el crítico que el aspecto más necesitado de una urgente ințervención del Ėstado es este último, pues la supervivencia de los artistas en activo se hace difícil a consecuencia de la crisis económica y de la ausencia de un comercio relativamente estable de obras de arte contemporáneo. JUAN DE LA ENCINA, "El arte y el Estado", y "El Estado y el arte", ambos en El Sol, 9 y 15 de agosto de 1934, respectivamente. ALZURI MILANÉS, M., "Juan de la Encina, crítico de arte", Juan de la Encina (1883-1963) y el arte de su tiempo, Madrid, Ministerio de Educación y Cultura, 1998, págs. 40-41.

${ }^{32}$ En efecto, las medidas adoptadas para desterrar las inágenes de cartón-piedra đarán su fruto, aunque quizás con mayor retraso del deseado; buena prueba de ello es el caso de Navarra, donde ya en la década de los sesenta, con la irrupción en el panorama escultórico religioso del valenciano José López Furió, podemos leer declaraciones como éstas: Pasaron ya ia Dios gracias!, los tiempos aquéllos en los que una persona piadosa y pudiente regalaba a la Iglesia una imagen, muy mona, de escayola, diseniada en Olot, o inspirada en modelos de esa escuela, si escuela se puede llamar a aquellos talleres... iMucho nos alegra el que se vayan introduciendo en el gusto estético -en el arte religioso- el deseo de colocar imágenes de talla, originales, en contra de aquéllas, inexpresivas y acarameladas, hechas en serie y con materiales
} 
Pero sin duda, la solución más clara que se propone para la reactivación del arte religioso es la vuelta del artista al sendero de la fe; son los propios artistas los que tienen la máxima responsabilidad, dejándose de quintaesencias y pedantes simbolismos y recuperando el buen gusto de cuantos supieron insuflar vida y sentimiento a sus obras.

\section{LA DOCTRINA ARTÍSTICA DE LA IGLESIA: LA RECUPERACIÓN DEL} BUEN GUSTO

En un discurso sobre el arte sagrado pronunciado por el papa Pío XI en 1932 con motivo de la inauguración de la Pinacoteca Vaticana, se refería a lo que llaman arte moderno" con severas palabras, invitando a que semejante arte no se admita en nuestras iglesias, y que, con mucha mayor razón, no sea invitado a construirlas, a transformarlas, a decorarlas; no obstante, daba la más sincera bienvenida a toda nueva manifestación artística que se haya estudiado o cultivado a la doble luz del genio y de la fe, y que en consecuencia posea el buen gusto que requiere la Majestad de Dios. ${ }^{33}$

En el Segundo Congreso de Arte Sagrado celebrado dos años más tarde, el pontífice insistía en el buen gusto como condición indispensable que el artista debe poseer, y así lo recordaba a los congresistas: La primera condición para la educación del buen gusto es tenerlo, aunque sea en pequeña cantidad. Es verdad aquello que dijo el poeta: a quien la naturaleza no dio buen gusto, mil Atenas y Romas no se 10 darán. Para el pontífice, el arte religioso sigue teniendo hoy en día un gran contenido didáctico, motivo por el cual su ejecución no puede quedar al arbitrio caprichoso de cualquier artista por grande que sea y que desconoce las leyes que lo condicionan. Hay unas normas, unas exigencias litúrgicas, que deben poner su sello en la creación artística de lo que atañe al culto, al arte en la iglesia. En el dogma, su interpretación no puede quedar al arbitrio de cada individuo. El arte religioso, que es una como enseñanza plástica del dogma, tampoco puede quedar a merced de las fantasías más o menos personales, más o menos atrevidas, de los artistas. En este sentido pueden ponerse las palabras aparecidas en la prensa española años más tarde en las que se afirmaba la necesidad de la formación espiritual del artista: ... creemos en la formación espiritual del artista como el único medio de conseguir que sus más precisas y privilegiadas intuiciones creadoras se muevan dentro de un ámbito temático más amplio y más profundo ${ }^{34}$. No olvidemos que el sector tradicional español identificó espiritualidad con religiosidad, y religiosidad con catolicidad ${ }^{35}$.

poco dignos!. "Fiesta de Cristo Rey". El Pensamiento Navarro. 31 de Octubre de 1965.

"Renacimiento de la escultura navarra". El Pensamiento Navarro. 30 de Diciembre de 1962.

33 "Suprema Congregación del Santo Oficio. Instrucciones sobre el arte sagrado". Fechada en

Roma, en el palacio del Santo Oficio, el 30 de junio de 1952.

${ }^{34}$ Escorial, Suplemento de Arte, núm. 1, otoño de 1942. Citado por LLORENTE, A., Arte e ideologia en el franquismo (1936-1951), Madrid, Visor, 1995, pág. 38. 
Si la doctrina de Pío XI fue encaminada hacia el buen gusto, Pío XII se percata de un grave problema como es el divorcio arte-religión, y trata de superarlo a través de diversos escritos que ponen de manifiesto la dimensión del asunto que nos ocupa $^{36}$. El papa es claro al destacar la noble misión del artista, y por ende del arte, el cual ayuda a los más insensibles y distraídos a ver, a gozar de la belleza natural de las cosas más humildes, y a través de ella, de la belleza divina, y a levantar los ojos hacia el cielo, hacia Dios ${ }^{37}$. Para el pontífice el artista es un intérprete, un traductor de Dios, ya que a través de su arte nos pone en relación con las grandezas del mundo ${ }^{38}$, y ataca enérgicamente a quienes tratan de desvincular el arte de la religión, porque toda belleza artistica que se quiera recoger en el mundo, en la naturaleza, en el hombre, para expresarla con sonidos, con colores, con juegos de masa, no puede prescindir de Dios, ya que todo cuanto existe está ligado a Él con relaciones esenciales. Es tajante al señalar que estas afirmaciones no suponen que el artista tenga que tratar explícitamente temas religiosos, ya que cualquier asunto resulta adecuado para expresar la grandeza de Dios, pero sí que manifiesta que a través de esta temática se han alcanzado las más altas cimas ${ }^{99}$.

Concretando más el camino que debe emprender el artista para superar este alejamiento de la religión, Pío XII se muestra partidario de la intervención de lo moderno en el arte religioso al señalar que no se deben despreciar y repudiar genéricamente y como criterio fijo las formas e imágenes recientes más adaptadas a los nuevos materiales con los que hoy se confeccionan aquéllas, si bien apunta que debe evitarse con un prudente equilibrio el excesivo realismo por una parte y el exagerado simbolismo por otra. Cree que resulta necesario dar campo libre al arte moderno, siempre que sirva con la debida reverencia y el honor debido a los sagrados sacrificios y a los ritos sagrados; y pone como ejemplo a Fra Angélico, quien estuvo siempre pronto y abierto para asimilar las nuevas corrientes renovadoras del arte, empeñándose en que éste conservara su carácter religioso tradicional dentro de su finalidad didáctica y ética ${ }^{40}$. La política del "justo medio" parece en consecuencia la más apropiada.

\footnotetext{
${ }^{35}$ LLORENTE, A., op. cit., pág. 38.

${ }^{36}$ Véase una recopilación de todos ellos en Arte Sacro. Pío XII y el arte, Madrid, 1957.

37 "A los pensionados de la Villa Medicis", 19 de mayo de 1948. En Arte Sacro. Pío XIr y el arte, pág. 15. Incide nuevamente sobre esta idea en su Carta al Congreso Internacional de Artistas Católicos, celebrado en 6 de septiembre de 1950, donde reitera el valor comunicativo del arte para acceder a Dios, si bien no llega a concretar el modo en que debe concebirse el arte para tal fin.

${ }^{34}$ En este sentido afirma que las obras de los artistas no sólo traducen en caracteres de fácil lectura y con lengua universal las verdades cristianas, sino que comunican el intino sentido y la emoción con una eficacia, un lirismo, un ardor, cual quizás no posee la más ferviente publicación. Las almas cultivadas, elevadas, preparadas por el arte, están más dispuestas a percibir la realidad religiosa y la gracia de Jesucristo.

39 "Carta a los expositores de la VI Cuadrienal Romana", 8 de abril de 1952. En Arte Sacro. Pío XII y el arte, págs. 21-24.
} 
Pese a su talante abierto y conciliador, el papa se manifiesta enérgico en su censura a determinado tipo de imágenes que han tratado de introducirse en el arte religioso: No podemos por menos, movidos por nuestro deber de conciencia, que deplorar y reprobar aquellas imágenes, recientemente introducidas por algunos, que parecen ser depravaciones y deformaciones del verdadero arte, $y$ que a veces repugnan abiertamente al decoro, a la modestia y a la piedad cristiana y ofenden miserablemente al genuino sentimiento religioso; estas imágenes deben mantenerse absolutamente alejadas de nuestras iglesias, como, en general, todo aquello que no esté en armonía con la santidad del lugar ${ }^{11}$. Partidario del decoro en todo aquello que tenga que ver con la liturgia, aun cuando no brille por su excesiva riqueza y esplendor, Pío XII afirma que el arte religioso debe ser apropiado y limpio, y determinadas corrientes artísticas -aunque no cita estilos ni autores- resultan del todo inaceptables.

Valorando la doctrina de la Iglesia en materia artística, son varias las conciusiones que se pueden extraer. En primer lugar, es necesario reorientar al artista hacia el buen gusto. $Y$ aunque no existe unanimidad al respecto, la norma válida parece ser la de aquellos artistas cuyas obras procuran ser una interpretación "comprensible" del arte y del dogma religioso, sin sacrificar la libertad o la fuerza de expresión; hay que lograr obras de profunda intensidad espiritual que conmuevan interiormente a quien las contempla, como lo hicieron los frescos de las catacumbas, los mosaicos de Roma y Rávena, las miniaturas y vidrieras medievales, o los primitivos italianos y alemanes ${ }^{42}$. El propio Pío XII insiste en la expresividad como cualidad indispensable para que el arte religioso cumpla con dignidad y fruto su verdadera misión: una primera condición se exige para que el arte pueda producir un tan deseable resultado: valor expresivo, ya que faltando éste deja de ser un arte verdadero. El señalario no es hoy superfluo, dado que frecuentemente, en algunas escuelas, la obra de arte no se basta por sí misma para exteriorizar el sentimiento, para revelar el alma de su autor ${ }^{43}$. En este sentido, determinados artistas como Maurice Denis, Gino Severini y sobre todo Georges Rouault -si bien hubo que esperar hasta 1945 para que una vidriera suya entrara por primera vez en una iglesia, se convierten en paradigmas del nuevo arte religioso en la primera mitad del siglo $X X$, ya que aportaron al cristianismo un aliento de verdad y de vida, de sinceridad y

\footnotetext{
40 "Del discurso al inaugurar la exposición de Fray Angélico en el Vaticano", 20 de abril de 1955. En Arte Sacro. Pío XII y el arte, pág. 27.

"1 PÍ XII, Encíclica Mediator Dei sobre la Sagrada Liturgia, 20 de octubre de 1947.

${ }^{42}$ La vuelta al pasado, y más concretamente al período y al espíritu medieval, es una solución que planea sobre buena parte de la crítica. Así lo creen, entre otros, Antonio Méndez. Casal, Juan de la Encina, o Fernando Jiménez Placer, quien encuentra en el estilo neogótico del pórtico de Chaillot, realizado por el escultor Henri Bouchard, una de las posibles vías de recuperación.

${ }^{13}$ PÍO XII, "Al Congreso Internacional de Artistas Católicos", 6 de septiembre de 1950. En Arte Sacro. Pío XIl y el arte, págs. 18-19.
} 


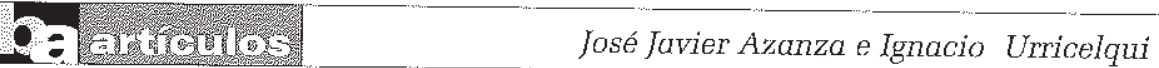

\section{Maurice Denis. "Dejad que los niños se acerquen a in $^{\prime \prime}$. L'Art Catholique, $n^{0} 247$}

de vigor en la fe, que se estaban echando en falta desde hacía más de un siglo.

Ya en 1895, cuando apenas contaba con 15 años de edad, escribía Maurice Denis en su Diario que era necesario intentar un esfuerzo por devolver el arte a su único dueño, que es Dios. En 1919 fundó junto con Georges Desvallières los "Ateliers de l'Art Sacré", destinados a formar artistas y artesanos interesados por la renovación del arte cristiano; a través de su

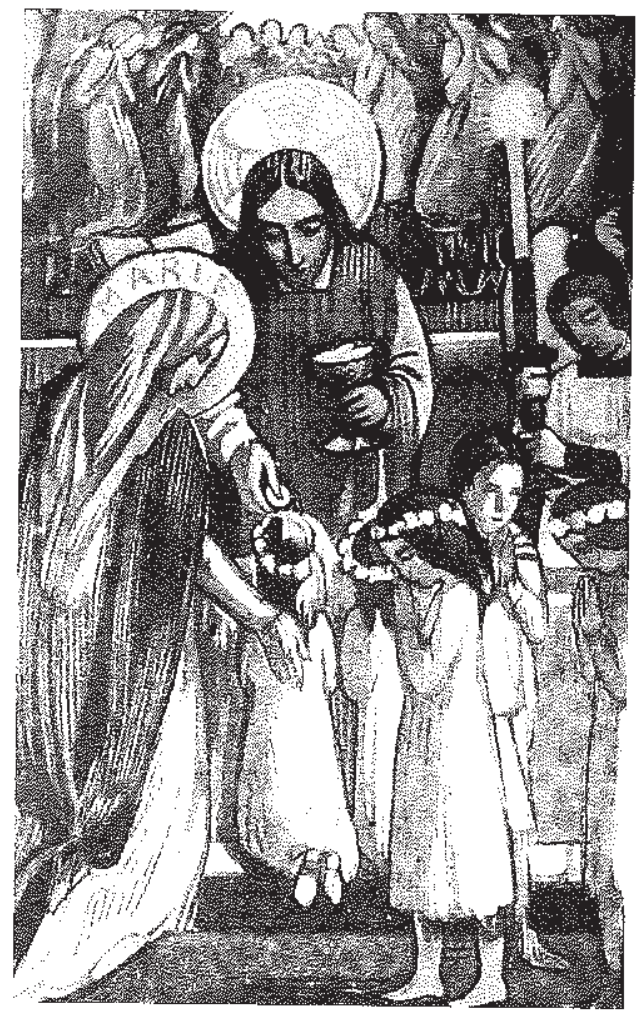
enseñanza ejerció una influencia en la pintura religiosa que se extendió hasta su muerte en 1943. Denis se convirtió así en el gran renovador del arte religioso y en el defensor de la espiritualidad católica del arte, buscando siempre en sus obras la armonía de las formas y de los colores y, por medio de ella, la expresión de la alegría cristiana (Fis. 5). El padre Donostia no duda en citar como modelo de buen gusto a Denis, pintor católico tan conocido y que en su libro "Charmes et leçons de litalie", delicioso volumen lleno de enseñanzas, y en sus "Theories y Nouvelles Theories", tantas lanzas ha roto en pro de un arte moderno religioso y digno ${ }^{44}$. También Juan de la Encina, al referirse a la pintura de Pedro Sánchez, encuentra en ella un brote de delicado arte religioso, el cual, como propugnan en Francia, con el ejemplo y la teoría, Maurice Denis, y otros muchos artistas católicos en toda Europa, no es incompatible con los modos más modernos ${ }^{45}$. En cuanto al italiano Severini, la transformación espi-

\footnotetext{
44 "De arte sagrado. Interesante artículo del P. Donosti". La Voz de Navarra. 30 de Noviembre de 1934. Véase también ANTSORENA MIRANDA, J.L., Aita Donostia, San Sebastián, Fundación Kutxa, 1999, págs. 216 y 267. Algunas reflexiones sobre el arte religioso de Denis se encuentran en DESTREMAU, F., "Les pèlerins d'Emmaüs de Maurice Denis", Gazette des Beaux Arts, t. CX, 1987, págs. 173-180

45 JUAN DE LA ENCINA, "Los nuevos modos y temas", La Voz, 22 de marzo de 1930.
} 
6. Georges Rouault. Cristo do los Ultrajes. 1946-49. Vidriera de la fachada oeste de la Iglesia de Assy

ritual que en torno a 1920 le hizo retornar a la fe católica vino acompañada de un cambio en su arte, abandonando el futurismo y adentrándose en un neoclasicismo basado en un elaborado conjunto de principios matemáticos ${ }^{46}$.

Por su parte, Georges Rouault se define a sí mismo como "pintor cristiano", como un hombre esencialmente religioso que dota de contenido espiritual a la obra de

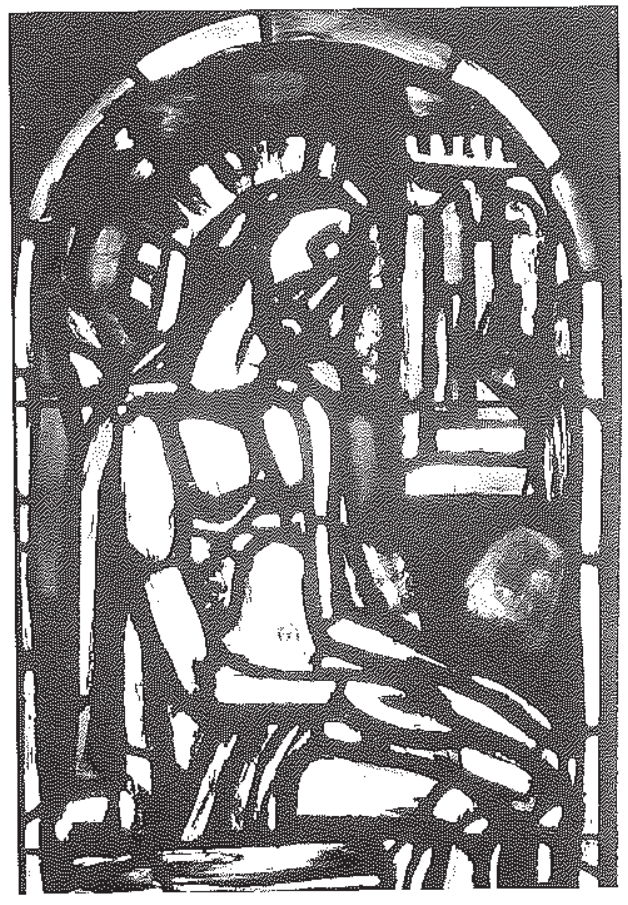
arte, pues ésta surge no como mero deleite o capricho o para otros fines poco dignos, sino como un imperativo moral proveniente de la conciencia del artista ${ }^{47}$. En consecuencia, toda su obra, incluso la de tema profano, estará imbuida por ese espíritu religioso que, como dijera su amigo el filósofo Jacques Maritain, puede manifestarse tanto en una sinfonía, un ballet o una novela, como en la vidriera de una iglesia. El propio artista reconoce esa espiritualidad en su pintura cuando, a propósito de su obra El payaso herido, realiza el siguiente comentario: en mi opinión, acaso sea tan religioso como algunas composiciones de título biblico. No basta con poner la rúbrica "arte sagrado" en algunas obras para darles un sentido religioso ${ }^{48}$.

Desde los comienzos de su carrera, Rouault mostró inclinación por las obras de temática religiosa, de manera que la Biblia se convierte en motivo constante de inspiración que plasmó en numerosos lienzos y vidrieras (Fig. 6). En la concreción de su lenguaje artístico juega un papel fundamental, además del ejemplo de los antiguos maestros de la tradición medieval, la obra tardía de Rembrandt, en la que

${ }^{46}$ SEVERINI, G., Del cubismo al clasicismo (estética del compás y del número), Murcia, Colegio Oficial de Aparejadores y Arquitectos, 1993.

${ }^{47}$ PLAZAOLA, J., "Georges Rouault", Razón y Fe, nº 723, 1958, págs. 364-372.

${ }_{18}$ LÓPEZ BLÁZZUEZ, Mr, Georges Rouault, Barcelona, Ediciones Polígrafa, 1997. 
predominan los temas religiosos que el viejo maestro trata con honda sensibilidad ${ }^{49}$. Así queda de manifiesto en lienzos como El niño Jesús entre los Doctores (1894), obra de profundo sentimiento religioso en la que tanto la composición como el empleo de la luz y el color resultan deudores del pintor holandés. Durante las dos décadas siguientes las obras religiosas escasean en su producción, hasta que en 1914 retoma el tema con mayor intensidad y marcando una ruptura radical con la pintura religiosa tradicional: si usted fuera un hombre de oración, no podría pintar estas horribles telas, llegaría a espetarle su amigo Léon Bloy. Sin embargo, Rouault está movido por un profundo sentido del arte religioso, aunque su religiosidad, simple, humilde y directa, se nos muestra en una especie de tono menor que huye de la grandilocuencia, dotando a sus obras de ese aire de objeto de devoción popular muy acorde con el sentido de la religión que tiene su autor. $Y$ así, en la exposición de arte sacro celebrada en 1950 en el Vaticano con más de 1.400 cuadros de la primera mitad de siglo llamaron poderosamente la atención las obras enviadas por el francés por su fuerza y expresividad, cualidades éstas que mueven a la oración, como manifiesta Marguette Bouvier: Tengo en mi habitación una escena mística de Rouault delante de la que rezo todos los días. Al arrodillarme frente a su cielo, que es un grito de angustia; a sus azules-verdes de fondo del mar, a sus rojos de puesta del sol, rezo con la misma emoción que delante de las vidrieras de Chartres, vidrieras que alegran el corazón. Los paisajes bíblicos de Rouault son, a la vez, una oración y una ventana abierta sobre el mundo de sus sueños. Quiero al pintor por su arte, su don de grandeza, su extraordinario poder de elevación y, más que todo, porque nos acerca a Dios, abriéndonos el camino de la Esperanza ${ }^{50}$.

Junto a la recuperación del buen gusto, los escritos pontificios dejan muy claro que la excentricidad no cabe en el arte religioso. Como señala Pío XII, la Iglesia se opone a toda obra carente de inspiración religiosa y en abierta oposición a las más elementales reglas del arte; no se puede permitir que, bajo el pretexto de "el arte por el arte", se proceda a la deformación o destrucción del cuerpo de las imágenes sagradas hasta el punto de volverlas irreconocibles, horribles o simplemente fantásticas: Porque no ignoramos que en estos últimos años algunos artistas, con grave ofensa de la piedad cristiana, han osado introducir en las iglesias obras carentes de toda clase de inspiración religiosa y en abierta oposición aun con las justas reglas del arte. Ellos tratan de justificar esta deplorable conducta con argumentos especiosos que pretenden hacer derivar de la naturaleza y de la indole misma del arte. Porque van diciendo que la inspiración artística es libre y no es lícito sujetarla a leyes y normas morales y religiosas, ajenas al arte, porque de este modo se llegaria a lesionar gravemente la dignidad del arte y a dificultar con ataduras y obstáculos el curso libre de la acción del artista bajo el impulso sagrado del estro.

\footnotetext{
49 Así lo significa Pierre Courthion al afirmar de Rouault que en el arte de Rembrandt encontró una generosidad y una espiritualidad que respondian perfectamente a las suyas. COURTHION, P, Georges Rouault, New York, Harry N. Abrams, 1977, pág. 17.

${ }^{50}$ BOUVIER, M., "Georges Rouault. Expresionista y místico", Goya, ño 25, 1958, págs. 18-24.
} 
Afirma el papa que las obras artísticas no han de juzgarse tan sólo con argumentos tomados de la estética, sino de acuerdo con el último fin del hombre, destinado por su naturaleza a imitar la infinita perfección de Dios. Y concluye Pío XII que la libertad del artista no se encuentra, por el hecho de estar sujeta a la ley divina, coartada o suprimida, sino más bien se ennoblece y perfecciona ${ }^{51}$.

También entre la crítica artística se eleva una conciencia que cuestiona la validez para el arte religioso de ciertas tendencias contemporáneas: Dios, los santos y los ángeles no son juguetes que se puedan libremente descomponer en pequeños cubos o destellos, bajo el pretexto de introducir en la pintura las conquistas de la ciencia atómica, o que se puedan recortar en círculos como el buen hombre hinchado de los neumáticos "Michelin", afirma Brans, a cuyo juicio las obras de temática religiosa de determinados pintores de vanguardia no son sino juegos de "enfants terribles" repletos de blasfemias. Juan de la Encina se posiciona al respecto desde las páginas de El Sol, criticando abiertamente la atolondrada anarquía y el imbécil snobismo de algunos artistas ${ }^{52}$, en tanto que Jiménez Placer, al alabar el trabajo de Henri Bouchard, autor de las obras del pórtico de la íglesia de San Pedro de Chaillot, señala que sus esculturas dan una lección a quienes impulsados por plausibles intentos renovadores, van más allá de lo debido, descarriándose en interpretaciones subjetivas de las augustas figuras y escenas del cristianismo ${ }^{53}$.

El creyente no pide al Arte que le enseñe a orar, pero tiene derecho a exigirle que no blasfeme. El Arte por el Arte sí; pero el Arte a costa de la Moral, no; y para muchos el Arte por el Arte ha significado -al menos en la práctica- esto último, significaba E. de Esparza en un comentario de $1921^{54}$. En este sentido, el cubismo es rechazado por tratarse de un estilo excesivamente frío e inexpresivo, deshumanizado, materialista y carente de cualquier atisbo de emoción religiosa ${ }^{55}$. Es más, algunos sectores conservadores de la crítica española lo atribuyeron al espiritu judaico internaciona ${ }^{56}$,

51 "De la Encíclica sobre música sagrada", 25 de diciembre de 1955. En Arte Sacro. Pío XII y el arte, pág. 36.

52 JUAN DE LA ENCINA, "El devoto Crucifijo", El Sol, 2 de agosto de 1935. El escepticismo de Juan de la Encina respecto al arte de vanguardia fue notorio, dejando constancia en numerosos artículos de su prevención ante determinados autores y movimientos como el cubismo, surrealismo y el "arte puro" en general, a los que acusaba de excesiva teoría, monotonía formal y escaso contenido estético. Pero tampoco se cerró completamente a las innovaciones que las vanguardias podrían aportar al aletargado arte español, concretándose sus preferencias estéticas en una equilibrada vía intermedia que podría calificarse de "modernidad clásica". ALZURI MILANÉS, M., op. cit., pág. 37. JIMÉNEZ-BLANCO CARRILLO DE ALBORNOZ, M.D., "Juan de la Encina, director del Museo de Arte Moderno", Juan de la Encina (1883-1963) y el arte de su tiempo, pág. 64. JUAN DE LA ENCINA, "EI té chino", La Voz, 23 de febrero de 1921. 53 JIMÉNEZ PLACER, F, "La nueva iglesia de San Pedro, en Chaillot", El Debate, art. cit. ${ }^{54}$ ESPARZA, E. de, "El Arte y la Moral", Euzkadi, 7 de julio de 1921.

${ }_{55}^{5}$ Véase al respecto el artículo de GUERRISI, M., "L'Estetica del cubismo", Fede ed Arte, $\mathrm{n}^{\circ} 7$, 1953, págs. 194-197. 


Y: = - José Javier Azanza e Ignacio Urricelqui

\author{
7. Emil Nolde. La \\ Adoración de los \\ Reyes. 1933. \\ Fundación Nolde
}

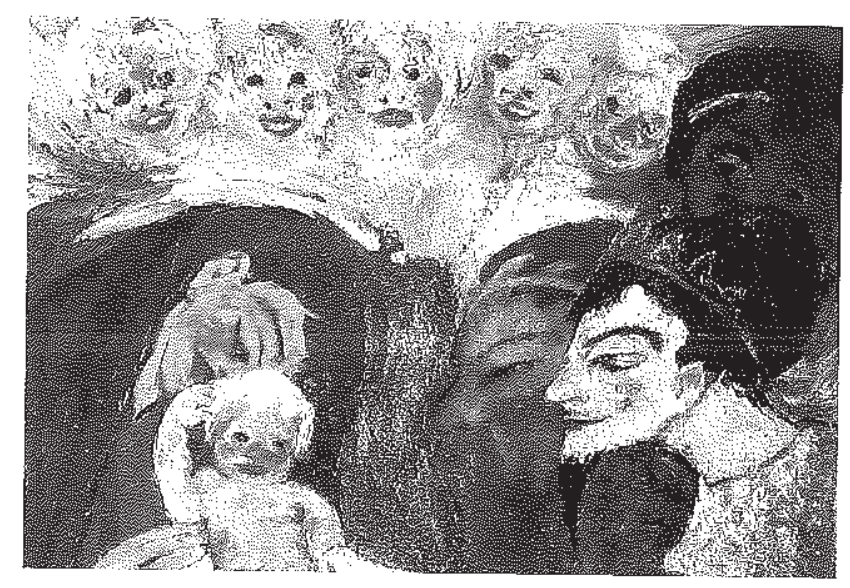

llegando a afirmar incluso que este movimiento era posible en las sociedades democráticas, pero imposible en una sociedad "jerárquica" como la franquista española ${ }^{57}$, si bien sí se aceptaron otras corrientes como el futurismo, sin duda por su vinculación al fascismo italiano. Pese a que estas apreciaciones corresponden a un punto de vista político, que durante el franquismo español mantuvo siempre una fuerte vinculación al aspecto religioso, no dejan de ser significativas para nuestro fin ${ }^{58}$. También los llamados "Cuadros bíblicos y de leyendas" de Emil Nolde fueron desde un principio motivo de escándalo (Fic. 7). Sirva como ejemplo el hecho de que, mientras el Museo de Halle adquirió en 1910 la Última Cena, siendo la primera obra expresionista en un museo, en 1912 las protestas de la jerarquía eclesiástica impidieron que se mostrara en la Exposición Internacional de Arte Religioso Moderno organizada en Bruselas por la Real Sociedad de Bellas Artes ${ }^{59}$; o la exposición que

\footnotetext{
${ }^{56}$ LLORENTE, A., op. cit., págs. 42-43. Algunas notas interesantes sobre este asunto se dan en un artículo anónimo aparecido en la revista Mundo bajo el título "La đeshumanización del arte", Mundo, $\mathrm{n}^{\circ}$ 402, 18 de enero de 1948.

57 "... en una sociedad jerárquica la pintura cubista es el máximo de los horrores que puedan contemplarse." ROS, S., "Arte y Política", Arriba, 23 de junio de 1939. Cit. por LLORENTE, A,
op. cit., pág. 45 .

${ }^{5 y}$ Un estudio sobre el arte en el período franquista, centrado en el marco de la I Bienal Hispanoamericana, es aportado por CABAÑAS, BRAVO, M., Política artística del franquismo, Mađrid, C.S.I.C., 1996.

${ }^{59}$ En sus escritos biográficos, Nolde reflexiona acerca de este suceso: Yo ignoraba, antes de que esto ocurriera, que tanto a los ministros de la Iglesia evangélica como al clero católico no les gustaban mis cuadros o no los quenan. Callaban. Yo, claro está no habla preguntado a nadie qué aspecto deben presentar las imágenes religiosas. Surgieron siguiendo enteramente mi propio instinto: los tipos humanos, también Cristo y los apóstoles, representados tal como fueran en realidad: labradores y pescadores judíos. Los pintaba como vigorosos tipos judíos, pues seguramente no eran enclenques quienes se pasaban a la nueva y revolucionaria doctrina de Cristo. REUTHER, M., "La pintura de Emil Nolde y sus cuadros religiosos", en Emil Nolde. Naturaleza y religión, Madrid, Fundación Juan March, 1997, págs. 12-13.
} 


6.

8. Salvador Dali. Asunción de la Virgen

en 1921 organizara Carl Georg Heise, director de los museos de Lübeck y apasionado partidario de la corriente expresionista, de los "Cuadros religiosos de Emil Nolde" en la iglesia de Santa Catalina de Lübeck, dando lugar a una agria polémica en torno a ese templo profanado sin escrúpulos ${ }^{60}$.

Pero hacia quien van dirigidas la mayor parte de las críticas es hacia

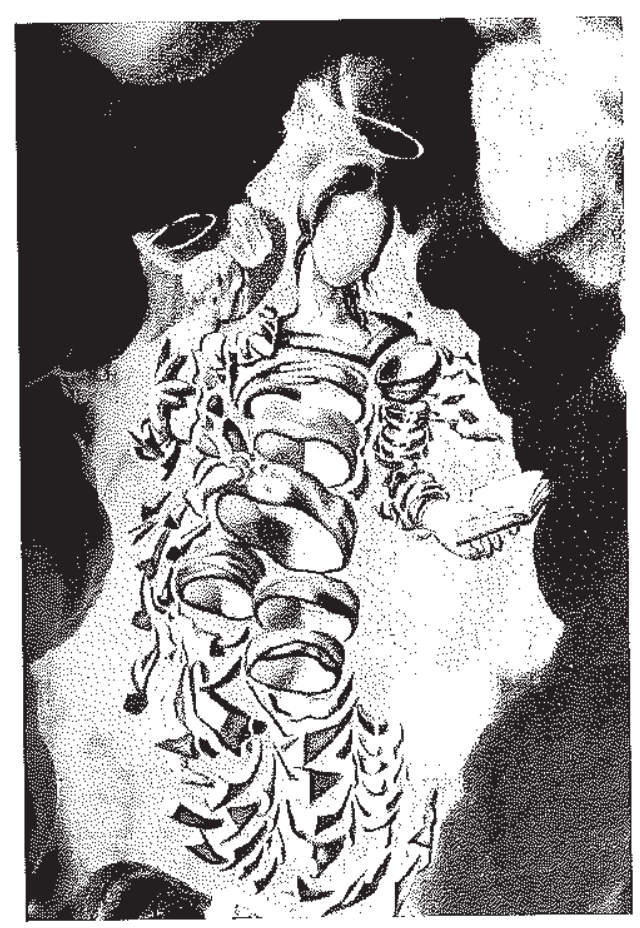
la pintura religiosa de Dalí, cuyo destino no era una iglesia, sino que del taller de Port Lligat iba directamente a un museo -con preferencia americano- o a una colección particular. En realidad el pintor no se sirve de sus cuadros para colaborar con el sacerdote en la misión de fomentar la devoción hacia Dios, sino que los expone en una sala pública para la admiración o censura de todo el mundo; tan sólo el asunto los separa del arte profano. ¿Podemos hablar entonces con propiedad de pintura religiosa? En estas condiciones, lo mínimo que se puede obtener es una frivolidad, cuando no una estrafalaria irreverencia ${ }^{64}$. Partiendo de esta apreciación inicial, la mayoría de los críticos consideran el surrealismo paranoico del pintor catalán totalmente contrario a ias exigencias elementales del arte religioso, cuya síntesis entre los motivos místicoreligiosos y los descubrimientos científicos del siglo XX resulta inaceptable ${ }^{62}$ (Fia. 8).

\footnotetext{
${ }^{60}$ Ibídem.

${ }^{61}$ BRANS, J.V.L., "La pintura religiosa de Dalí", Goya, nº 21, 1957, pág. 156.

${ }^{62}$ Acerca del sturrealismo religioso de Dalí Brans refiere lo siguiente: Mientras que Dalí aplica su surrealismo paranoico a imágenes profanas nos divierte alguna vez con su mordiente ironía o nos asquea con la desfloración brutal de nuestras ilusiones... Con el despiezo de la Virgen y la cabeza de un ángel Dalí nos recuerda, en efecto, el programa surrealista de demolición total de las tradiciones cristianas y de los fundamentos espirituales de la cultura occidental. Las excentricidades que caracterizan esta categoría son contrarias a las exigencias elementales del arte religioso; sobrepasan, en mi opinión, los límites de una experiencia o de una revolución artísticas. BRANS, J.V.L., op. cit., págs. 158-164.
} 
Incluso cuando Dalí se esfuerza por alcanzar la posibilidad real de una pintura surrealista acorde con las normas del arte sagrado, cuando decide adoptar un estilo más "clásico" y proclama su vuelta al Renacimiento, la crítica, cansada de tanta extravagancia, sigue manteniendo cierta desconfianza en el nuevo rumbo emprendido, como queda de manifiesto en el comentario al Cristo de San Juan de la Cruz expuesto en 1951 en Londres ${ }^{63}$. Obras como la Madonna de Port Lligat fueron acusadas de un manierismo frío y afectado y de la excesiva sumisión a los modelos del Renacimiento italiano. Además, y pese al cambio, su pintura religiosa sigue dominada por la búsqueda sistemática de lo extraordinario, por la ambición de asombrar, y prevalecen en ella los intereses publicitarios por encima de los devocionales -Gaya Nuño lo denomina "prestidigitador del arte"-., de manera que nunca podremos hablar de una pintura religiosa en sentido pleno. $Y$ lo que es más importante, todo artista religioso debe procurar encontrarse cercano a Dios y vivir su fe con autenticidad: y mientras Dali evite este ferviente contacto su pintura religiosa permanecerá ajena a la vibración vital, que es la mayor cualidad de la obra artística verdaderamente acabada y la única que tiene el poder mágico de conmover al espectador o inclinar su alma a la oración ${ }^{64}$.

Las anteriores reflexiones resultan igualmente válidas para al arte abstracto: ¿puede el arte abstracto ser religioso? $O$, concretando más: ¿puede una obra abstracta presidir un espacio sacro $?^{65}$. La doctrina de la iglesia parece oponerse a tal opción cuando rechaza el simbolismo exagerado. En todo caso podría aceptarse que el arte abstracto impone una especie de ascetismo en la percepción del mundo sensorial, que puede favorecer la elevación del alma hacia realidades espirituales, pero sin llegar más allá: el cristianismo es una religión de encarnación; por lo cual, el arte no figurativo en símismo no tiene alcance especificamente cristiano. Cristo vino para ser visto y para ser tocado. ¿Por qué vamos a intentar sustituir una serie de abstracciones a esta realidad querida por Dios?, se afirmaba a mediados de siglo.

No obstante, creemos que resulta sumamente interesante comprobar la opinión que al respecto mantienen algunos de los artistas del momento, como Albert

\footnotetext{
${ }^{63}$ Ha dicho Dall, ese llamativo sefior que pinta muy bien, que él está de vuelta del surrealismo, y que los surrealistas tendrán que seguir su camino. Y como muestra de lo que es su pintura actual, acaba de realizar un cuadro de Cristo... No cabe duda de que como pintura, técnicamente, es una obra maestra. Haría falta ver el lienzo para comprobar si, como se ha escrito de él, es una afirmación de inspiración mística, que emociona, que tiene una gran serenidad, después de haber contemplado tanta extravagancia. Éste es el Cristo que ha llevado Dalí a Londres. El Pensamiento Navarro. 11 de Diciembre de 1951. Gaya Nuño se refiere a las pinturas de Dalí expuestas en el Teatro María Guerrero de Madrid con motivo de la I Bienal Hispanoamericana de Arte como "títeres de feria traídos por un fabuloso prestidigitador del arte". "Dalí, epílogo de la Bienal y de sí mismo", Insula, ti ${ }^{\circ}$ 75, 1952, pág. 8. Cit por CABAÑAS BRAVO, M., op. cit., págs. 512-13.

${ }^{64}$ BRANS, J.VL., op. cit., pág. 164.

${ }^{6.5}$ Véase al respecto la obra de DEBIDOURD, V. H., Problèmes d'art sacré, París, 1951.
} 
Gleizes, quien se preguntaba: El problema del arte religioso es un problema de realidad. Pero ¿dónde está la realidad? ¿En lo que tocamos? ¿O más allá de las apariencias, en una realidad que sólo puede sugerirse y cifrarse en signos que encuentra el arte?. El arte religioso del siglo XX se sintió liberado de la función didáctica que había desempeñado en siglos pasados, de manera que, ante los temas sagrados, muchos artistas prefirieron "cantar" antes que "contar", es decir, expresar su emoción. Uno de los paradigmas del arte abstracto, Vasili Kandinsky, defiende en su obra De lo espiritual en el arte, publicada por primera vez en 1912, que el arte tiene que conmover el ánimo del espectador, para lo cual debe tender hacia la espiritualidad, hacia el interior, donde para él se encuentra la belleza ${ }^{66}$. En este sentido, ni afirma ni niega la capacidad religiosa del arte abstracto, simplemente da por supuesta su condición para conmover a la persona hacia fines espirituales más elevados mediante el adecuado empleo de formas y colores. Reconoce que ante la ya comentada crisis de valores del mundo actual, el hombre se ha apartado de lo externo y se ha centrado en su intimidad, a través de la cual llega a to espiritual $^{67}$. Para él, el fin no determina los medios que el artista debe usar, de manera que si éste es religioso, no importa las formas que se empleen: la pintura es un arte -afirma-, y el arte no es una creación inútil de objetos que se deshacen en el vacio sino una fuerza útil que sirve al desarrollo y a la sensibilización del alma humana... El arte es el lenguaje que habla al alma de cosas que son para ella pan cotidiano, que sólo puede recibir en esta forma ${ }^{68}$. De sus palabras parece desprenderse en consecuencia que lo abstracto puede llevar a la emoción religiosa.

El arte abstracto -escribía un escultor-por su ausencia total de figuración, podría ser el arte religioso por excelencia. Abre perspectivas inmensas a la contemplación y no pone obstáculo alguno a la piedad del creyente, sino que, al contrario, favorece la contemplación interior. A este planteamiento obedece la obra de determinados artistas que no juzgan necesaria la figuración en el arte religioso; al contrario, piensan que si algún terreno es apropiado para el arte abstracto, éste es el del sentimiento religioso, el mundo de lo trascendente. $Y$ concretamente el mundo de las realidades cristianas. El arte abstracto, precisamente por serlo, puede tener un alcance religioso y convertirse en una invitación al recogimiento y a la plegaria, en una llamada a la interioridad ${ }^{69}$. Así pareció entenderlo el padre Régamey cuando defendía la pintura abstracta de Manessier (Fic. 9) y Bazaine como precisos ejemplos del tipo de arte que

\footnotetext{
${ }^{66}$ Bello es lo que interiormente es bello. KANDINSKY, V, De lo espiritual en el arte, Barcelona, Barral-Labor, 1986, pág. 117.

${ }^{67}$ Cuando la religión, la ciencia y la moral se ven zarandeadas y los puntales externos amenazan derrumbarse, el hombre aparta su vista de lo exterior y la centra en símismo. La literatura, la música y el arte son los primeros y muy sensibles sectores en los que se nota el giro espiritual de una manera real. Inmediatamente reflejan la sombría imagen del presente, la gran oscuridad que aparece apenas esbozada. Ibídem, pág. 40.

6r Ibídem, pág. 114.

69 PLAZAOLA, J., Historia y sentido del arte cristiano, págs. 960-961.
} 
9. Alfred Manessior. Alleluia I. Colección Ph. Leclercq. Hem

no necesitaba ser explicado "en términos verbales" ${ }^{170}$.

\section{¿LA FE COMO CONDICIÓN INDISPENSABLE PARA ILUMINAR EL ARTE?}

Sin embargo, la polémica no termina aquí. Algunos de los artistas anteriormente mencionados como Denis, Severini y Rouault son católicos, pero ¿resulta la fe condición esencial para iluminar el arte, o la

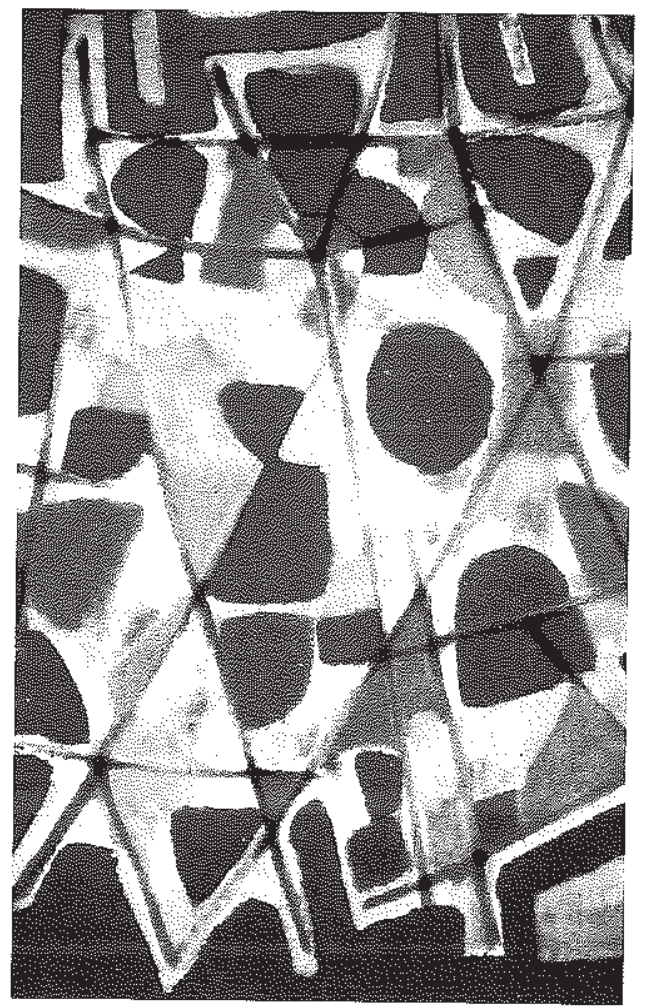
creatividad del artista puede plas-

mar en piedra, luz y color, las verdades de la fe aunque no sea creyente? ¿Es admisible que un pintor como Matisse, comunista notorio, se encargue de la decoración de la capilla del Rosario de las monjas dominicas de Vence, en los Alpes Marítimos? ${ }^{71}$.

Para sobresalir en pintura religiosa no basta componer bien, ser gran dibujante, colorista y ejecutante: hace falta algo que no está en la punta del lápiz, ni en la paleta, ni en la mano; algo propio del alma, puramente espiritual, que no depende de la voluntad: la fe, y no la vulgar, que cree instintivamente, en parte por precepto, en parte por pereza del entendimiento, sino la fe que hace feliz al creyente y se deleita a si

70 RÉGAMEY, PR, "Rome 1950", L'Axt Sacré, ño 5-6, 1951, págs. 22-26.

${ }^{71}$ Es alto el grado de indefinición que se produce en la capilla del Rosario de Vence, en la que no resulta fácil establecer la frontera entre emoción religiosa y emoción estética. El esmero en evitar la representación de figuras materiales y el refinamiento en la selección y empleo de formas y colores que pudieran calificarse de "espirituales", convierten a esta capilla, para algunos, en una de las más altas cimas del arte religioso contemporáneo; para otros es tan sólo una demostración de que la colaboración de los grandes artistas agnósticos no puede conducir más allá de esa "zona de nađie" ел que se confunden lo religioso y lo estético. PLAZAOLA, J., Historia y sentido del arte cristiano, págs. 959-960. 
misma. Así de rotundo se muestra Jacinto Octavio Picón en su crítica a la Exposición Nacional de 1897, significando que no basta el buen oficio para producir una obra religiosa, sino que para ello es indispensable la fe del artista ${ }^{72}$. Pocos meses después estas palabras eran refrendadas por otro de los grandes críticos del momento como es Luis Alfonso; en su valoración sobre la pintura religiosa de su época dejaba claro cuál había sido la principal causa de la decadencia del género: Todos, absolutamente todos los intentos efectuados en lo que va de siglo para producir cuadros religiosos, han fracasado... han podido triunfar como dibujantes, como coloristas, como compositores, como eruditos, de cualquier manera, menos como pintores genuinamente religiosos. A todos ha faltado lo esencial, aun poseyéndolo todo, hasta el genio: les ha faltado la fe. Asi, una candorosa Virgen de Fray Angélico, o un Ecce Homo escuálido de Morales, dicen más (como que dicen creo) que las composiciones más famosas y con más suma de talento y de saber pintadas por los más eximios artistas de doscientos años acá. Honrarán las obras de éstos un Museo: merecer un altar, sólo aquéllas ${ }^{73}$.

Durante la primera mitad del siglo XX la crítica se vuelve a manifestar en el mismo sentido, especialmente a través de los periódicos católicos, que son los más sensibles a la decadencia del arte religioso; significativas son las palabras de Antonio Méndez Casal en la revista Blanco y Negro, considerando imprescindible la fe en el artista religioso: Para crear una obra candorosa, ingenua, religiosa, la primera condición que se requiere es candor, ingenuidad, fe. Producir tales cualidades artificialmente es algo que se halla fuera de las posibilidades humanas ${ }^{74}$. También Alfonso López Quintás insistirá, en un estudio sobre arte sacro y sociedad de carácter marcadamente sociológico, en la necesidad de que el artista profundice en el misterio de Dios si quiere alcanzar cotas verdaderamente dignas en este terreno y no quedarse en el mero ejercicio de destreza técnica ${ }^{75}$.

$\overline{72}$ OCTAVIO PICÓN, J., "La Exposición de Bellas Artes", pág. 343. El autor señala además que la falta de fe que caracteriza a los artistas actuales va acompañada de la carencia de cultura necesaria para interpretar las páginas del Evangelio con sujeción a lo que pide la crítica histórica, y de inspiración para representar los misterios cristianos, por lo que, concluye, venimos a deducir que la pintura religiosa de estos dias anda a cien leguas de nuestra tradición como creyentes y de las exigencias del espíritu modemo.

${ }_{73}$ ALFONSO, L., "El axte a final del siglo. La pintura (2)", La Ilustración Española y Americana, $\pi^{\circ}$ XXXVIII, pags. 223-24.

${ }_{74}$ MÉNDEZ CASAL, A., "El arte religioso moderno. Su decadencia", art. cit. El autor incide de nuevo en la idea de que la crisis del arte moderno deriva de una crisis más honda que marca la vida moderna: El hombre no pulsa su vida interior. Su misión fundamental es la de actuar incesantemente en una carrera frenética, en la cual el que desfallece retrasa el alcance de una meta casi siempre ilusoria... La meditación serena, el reposo del espíritu, la elaboración lenta y emocionada de una obra no pueden tener realidad en plena carrera, cuando es menester evitar atropello. Y el artista, en su preocupación de no ser atropellado, olvida que está atropellando su propia obra... De ahí el desaliento que se observa en el arte religioso actual.

${ }_{75}$ LÓPEZ OUINTÁs, A., "Arte sacro y sociedađ", en Las artes en la Sociedad Española del siglo XX, Madrid, Editora Nacional, 1967, pág. 69. 
La mayor parte de los artistas que se pronunciaron al respecto coinciden con la anterior afirmación, caso de Maurice Denis, quien en sus Théories afirma que todo sentimiento producido por una obra de arte procede inconscientemente, o casi, del estado del espíritu del artista. "Quien quiera pintar la historia de Cristo, debe vivir con Cristo", dijo Fra Angélico. Es una verdad incontestable ${ }^{176}$. En el caso de Georges Rouault, su carácter de artista cristiano se concreta no tanto en la elección de unos determinados motivos como en una actitud general ante la vida; de esta manera, Rouault vendría a corroborar la teoría de su íntimo amigo el filósofo Jacques Maritain, para quien el arte cristiano se define por el sujeto en quien se da, y en este sujeto es imposible disociar la parte de artista y la de cristiano ${ }^{77}$.

Pero sin duda quien más se significó en esta polémica fue Gino Severini, a cuyo juicio quien toma en sus manos una obra artística destinada a mover a la oración, a exaltar a los santos, a honrar al Señor, no puede contentarse con ser solamente artista y poseer aquellas cualidades humanas y naturales de primer orden; necesita también ser "creyente", y quie toda su vida interior esté apoyada en la Iglesia materna de la que debe comprender su significado en relación con Dios, con el individuo y con la sociedad. Severini recuerda que el arte de la Iglesia está destinado a suscitar la plegaria, y pone un ejemplo muy ilustrativo: Se puede realizar una obra maestra pintando una "maternitá" y esta obra ejemplar, por el solo hecho de su autenticidad, se elevará espontáneamente hacia Dios; pero podría ocurrir que esta "maternitá" no fuese nunca una Madonna: entre la "maternitá" y la Madonna parece que sólo existe un cabello de diferencia, pero en realidad hay un abismo. Aborda por tanto el italiano una cuestión de contenido, aseverando que mientras el arte se emplee con fines exclusivamente religiosos, ha de mantenerse obediente al fin que con anterioridad se ha fijado. Por eso Severini, al preguntarse si es posible el arte religioso, responde de forma dubitativa, pero con la condición de apoyarse en una fe sincera, subordinando siempre este arte a un objetivo que le supere. El artista debe tener a Dios en el alma, y el lienzo o la escultura deben ser expresivamente religiosos: la expresión y el sentimiento de Dios al morir, de la Santa Virgen y de los Santos que sufren, no es necesario buscarlos en ideas externas, siempre nocivas, ni en el estudio psicológico de la naturaleza humana, es preciso tomarlos del propio corazón, simpatizando profundamente con el sufrimiento de Cristo y de los Santos ${ }^{78}$.

Mediada ya la centuria, el pintor informalista William Congdon vuelve a mostrarse claro al respecto: Sólo la fe en Jesucristo, Hijo de Dios y Redentor del hombre, y la urgente necesidad en el artista de saber lo que significa únicamente el hecho de ser salvado en la economía de la eterna salvación crearán un arte digno de ser colocado en la iglesia. Sólo cuando la gracia entre en el alma del artista será su arte digno de

\footnotetext{
${ }^{76}$ CHIPp, H. B., op. cit, pág. 115.

${ }^{77}$ LÓPEZ BLÁZQUEZ, M., op. cit.

${ }^{78}$ CONSIGLIO, C., op. cit., págs. 117-118.
} 
la Iglesia... No es tanto la falta de conocimiento artístico en el creyente lo que hoy se nota, cuanto la falta de fe en el artista ${ }^{79}$.

Como no podía ser menos también la Iglesia, principal comitente de arte sacro, se pronuncia a través de las palabras de Pío XIl: El artista que no profesa las verdades de la fe o se halla lejos de Dios en su modo de pensar y de obrar, de ninguna manera debe ejercer el arte sagrado, ya que no tiene, por decirlo así, ese ojo interior con el cual puede ver lo que exigen la majestad y el culto a Dios; ni es de esperar que sus creaciones, ajenas a la religión, que por otra parte muestran que es un hombre perito en su arte y dotado de cierta habilidad externa, sean capaces de inspirar esa piedad que dicen bien con el templo de Dios y su santidad, y dignas, por tanto, de que sean admitidas en los lugares sagrados por la lglesia, que es juez y guardiana de la vida religiosa $a^{80}$. Incluso el papa va más ailá al considerar esencial la fe no ya sólo en el artista religioso, sino en el artista en general: cuanto más el artista vive la religión, tanto mejor preparado está para hablar el lenguaje del arte, para entender sus armonías; para comunicar sus latidos; y señala la necesidad de que el artista, antes de buscar a Dios en la naturaleza y en el resto de los hombres, cuide de buscarlo dentro de sí mismo ${ }^{81}$. En consecuencia, anima a los artistas a que "aun sin proponéroslo expresamente como finalidad, tratéis de educar los espíritus tan fácilmente inclinables hacia el materialismo, en el gusto espiritual ${ }^{\text {22. }}$.

Sin embargo, también encontramos partidarios de la tesis contraria, aquéllos que piensan que el arte puede aicanzar elevadas cotas de religiosidad aunque sus creadores se encuentren poco o nada movidos por un sentimiento profundamente religioso. Quizás uno de los casos más complejos resulte el de Nolde, atormentado espiritualmente por sus muchas y violentas batallas interiores, quien acerca del origen de sus primeros cuadros de contenido bíblico de 1909 afirma que obedecíal irresistible anhelo de representar una profunda espiritualidad, religión e intimidad, pero sin mucha voluntad, conocimiento ni reflexión. Su arte religioso se mueve siempre fuera del marco eclesial dogmático y surge de una religiosidad personal natural: de haber estado vinculado al texto bíblico y a la rigidez de los dogmas, no creo que hubiera sido capaz de pintar tan vigorosamente esos cuadros vividos con hondo sentimiento: La Úlitima Cena y Pentecostés, confiesa sin reservas. Necesitaba ser artísticamente libre, no tener a Dios delante de mi como un inflexible rey asirio, sino a Dios dentro de mí, ferviente y sagrado como el amor de Cristo. Nolde

\footnotetext{
${ }^{79}$ Liturgical Arts, Nueva York, 1963, pág. 27.

so "De la Encíclica sobre música sagrada", 25 de diciembre de 1955. En Arte Sacro. Pío XII y el arte, pág. 38.

${ }^{81}$ Pío XII considera al artista un privilegiado entre los hombres, pero al artista cristiano lo eleva a la condición de elegido, porque es propio de los elegidos contemplar, gozar y expresar las perfecciones de Dios. Ver "Carta a los expositores de la VI Cuadrienal Romana, 8 de abril de 1952", en Pío XII y el arte, op. cit, págs. 22-23.

82 "Pío XII recibió a más de 200 artistas", Diario de Navarra, 9 de abril de 1952.
} 


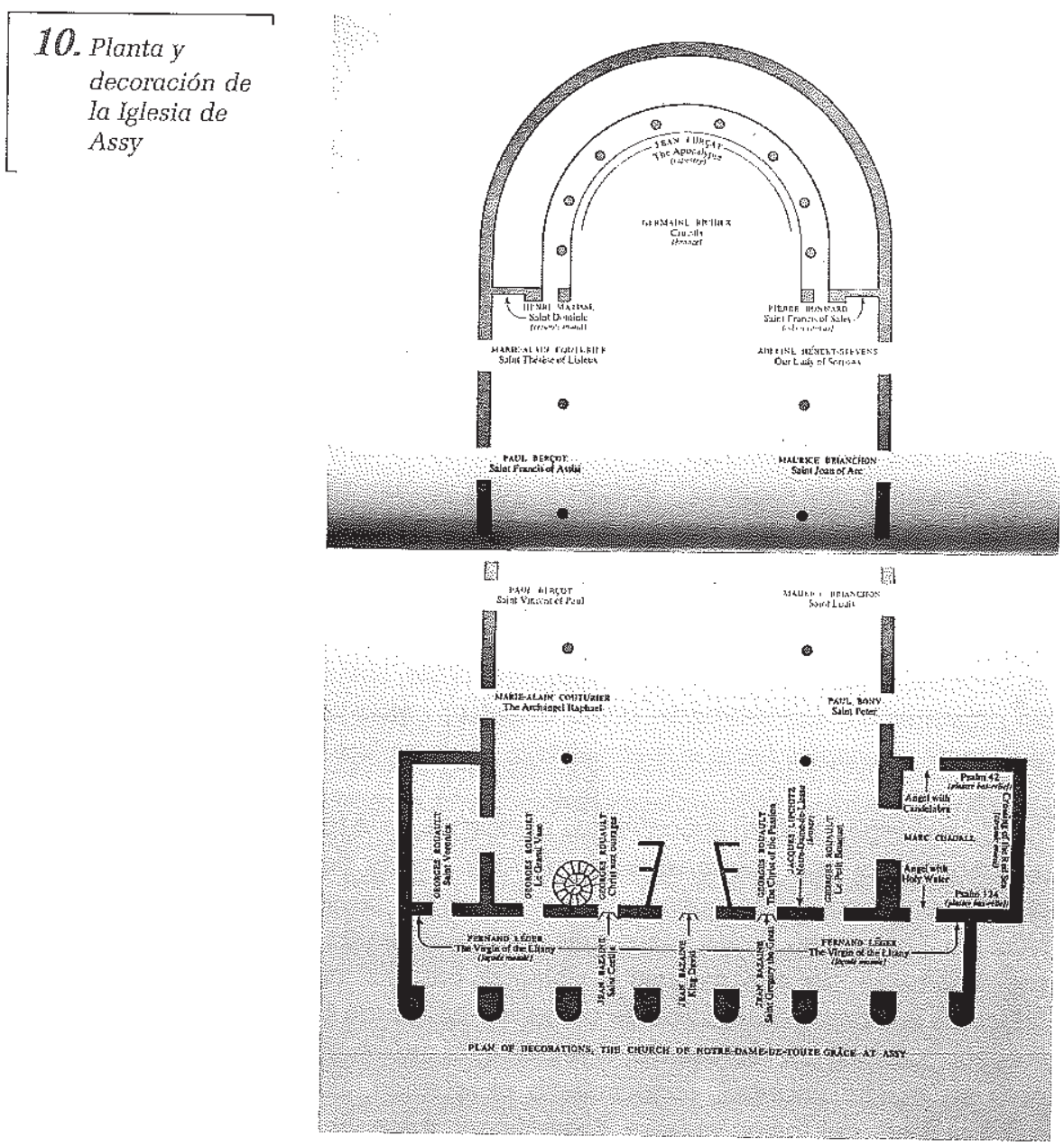

desarrolla en consecuencia un arte nuevo de influencia cristiana nacido de una total subjetividad y emotividad anímica; así se comprende que el arte expresionista de Nolde permaneciese marginado del ámbito eclesial y sólo tardíamente, tras largas polémicas, fuera aceptado por la lglesia. ¿Dónde están las paredes de los templos, ayuntamientos y paraninfos que deberian estar pintadas por Marc, Schmidt-Rottluf, Heckel, Kirchner?, se pregunta con aire de resignación. ¿Quién ha visto las capillas, iglesias y espacios en los que se ha permitido a mujeres que pintan y a pintores incapaces realizar importantes encargos? Hace tiempo que he dejado de pensar en mi como artista al que también habria podido tenerse en cuenta, a no ser que fuera en sueños ${ }^{83}$.

${ }^{\text {B3 }}$ REUTHER, M., op. cit., págs. 15-16. 
Pero sin duda la postura más beligerante en este terreno fue adoptada por el canónigo Jean Devémy y el dominico padre Marie-Alain Couturier en su proyecto de decoración de la iglesia de Notre-Dame-de-Toute-Grâce de Assy, en la Alta Saboya, construida entre 1937 y 1941 por el arquitecto Maurice Novarina, y que se convierte en una especie de Panteón de las glorias artísticas contemporáneas ${ }^{84}$. Las avanzadas ideas de Couturier en el terreno del arte se plasman en la siguiente reflexión: Desde Miguel Ángel a Tintoretto, las mejores corrientes artísticas salieron siempre de la Iglesia. Pero a partir del siglo XIX, todo cambia. Los mayores templos son los peores monumentos artísticos: Lisieux, Lourdes, etc. Si hubiera habido sacerdotes que prestaran su confianza a los grandes artistas, aun cuando éstos no hubieran sido creyentes, ¿no pudiéramos presentir lo que serian hoy nuestras iglesias?. Admitía Couturier que lo idóneo sería que el arte cristiano fuera resucitado por genios que al mismo tiempo pudieran convertirse en santos, pero en las actuales condiciones, puesto que esta clase de hombres no existe, resulta más seguro dirigirse a genios sin fe que a creyentes sin talento ${ }^{85}$.

En coherencia con su razonamiento, canónigo y dominico llamaron a la puerta de los más renombrados artistas del momento, sin tener en cuenta las lealtades religiosas o no religiosas y convencidos de que honraban a Dios ofreciéndole lo mejor que tiene el arte vivo (Fia. 10). A Rouault, que acababa de celebrar una exposición de vidrieras en el Petit Palais, se le encargaron cinco vidrieras para la fachada. Tras entrevistarse en Niza con el ateo Pierre Bonnard, éste envió un San Francisco de Sales, el mejor de sus cuadros y uno de los más excelsos de la pintura moderna para el altar lateral de la nave norte; y el incrédulo Matisse hizo lo propio con una efigie Santo Domingo para el de la nave sur, un simple dibujo negro en azulejos vidriados color hueso, acompañado a ambos lados por uvas y hojas de parra (FiG. 11). Braque trabajó los bronces de la puerta del sagrario y hasta el marxista Jean Lurçat -pese a su negativa inicial- contribuyó generosamente a la decoración con un tapiz para el altar mayor que representaba una escena basada en el caṕtulo 12 del Apocalipsis (Frg. 12). Ante el altar se colocó el Cristo de bronce de la escultora expresionista Germaine Richier, aterradora figura de tronco calcinado y cuerpo sin rostro, sin articulaciones y sin miembros, ante cuya contemplación el padre Couturier inmediatamente evocó los versículos del capítulo 53 del profeta Isaías ${ }^{86}$ (Fia. 13). Otros

${ }^{84}$ Sobre lo qué supuso la decoración de la iglesia de Assy en el panorama del arte sagrado, véase la obra de RUBIN, W. S., Modern Sacred Art and the Church of Assy, New York and London, Columbia University Press, 1961; una reseña del libro es realizada por Kenneth C. Lindsay en The Art Bulletin, XLV, 1963, págs. 82-83. Consúltese también OCHSÉ, M., op. cit., págs. 80-83. Y el artículo de SCHNEL, H., "Die Kirche in Assy: 1945-1947", Das Münster, 1950, pág. 34.

${ }^{85}$ COUTURIER, M. A., "Religious Art and the Modern Artist", Magazine of Art, $\mathrm{n}^{\circ}$ 7, 1951, págs. 268-272.

${ }^{86}$ No había en él belleza ni esplendor, su aspecto no era atractivo. Despreciado, rechazado por los hombres, abrumado de dolores y familiarizado con el sufrimiento; como alguien a quien no se quiere mirar, lo despreciamos y lo estimamos en nada. Sin embargo, llevaba nuestros 


\section{Q- José Javier Azanza e Ignacio Uricelqui}

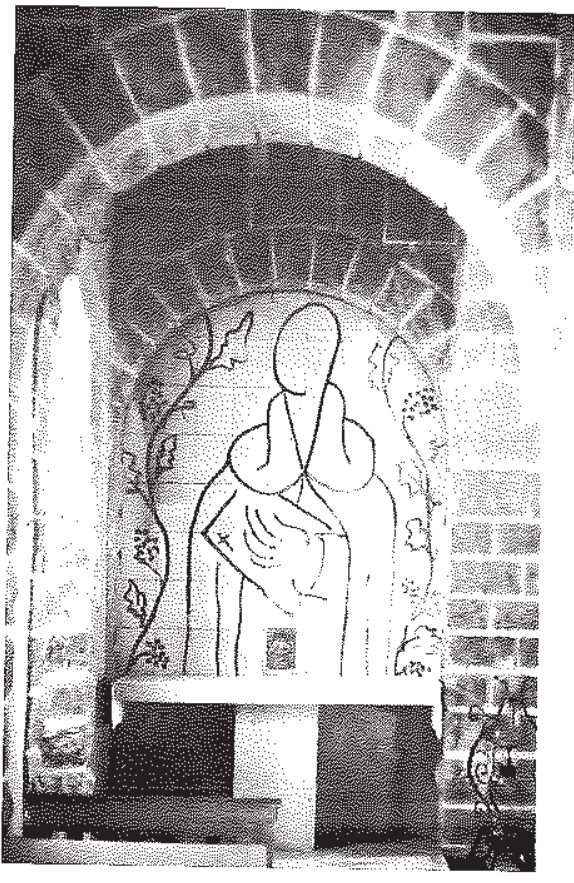

11. Henri Matisse. Mural cerámico de Santo Domingo. 1948. Iglesia de Assy

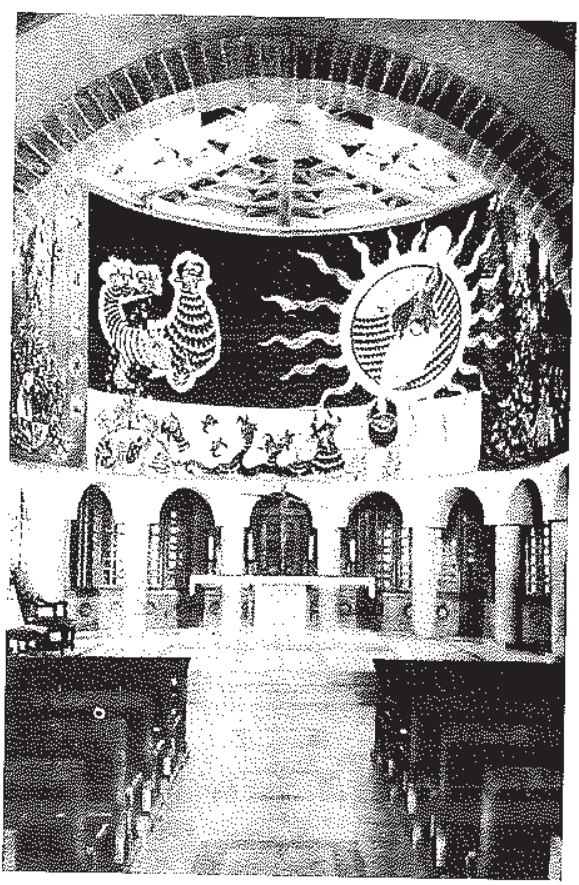

12. Joan Lurçat. Tupiz del Apocalipsis. 1945. Iglesia de Assy

artistas que participaron igualmente en la decoración de la iglesia de Assy fueron el comunista Fernand Léger, que compuso el mosaico de la fachada dedicado a la Virgen de la Letanía (F/G. 14), Jacques Lipchitz, a quien se le encargó una Madonna de bronce (Fig. 15), Jean Bazaine con otro conjunto de vidrieras, y el judío Marc Chagall, que representó a los israelitas atravesando el Mar Rojo en un mural cerámico del baptisterio (FiG. 16) ${ }^{87}$.

Yo creo en Dios cuando trabajo, había escrito Matisse en un álbum de papeles recortados titulado Jazz ${ }^{\text {a. }}$. En este sentido estaba de acuerdo con la opinión del padre Couturier, quien creía que sin tener en cuenta las elecciones políticas

dolores, soportaba nuestros sufrimientos. Aunque nosotros lo crefamos castigado, herido por Dios y humillado, eran nuestras rebeliones las que lo traspasaban, y nuestras culpas las que lo trituraban.

87 "El arte sagrado francés en ruda conmoción". El Pensamiento Navarro. 8 de Mayo de 1952, pág. 6.

вв MATISSE, H., Jazz, París, Editions Verve, 1947. 


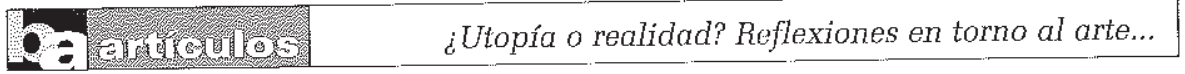

\section{Germaine Richier.Cristo \\ Crucificado. 1948. Iglesia de Assy}

14. Fernand Léger. Mosaico de la Virgen de la Letanía. 1945-1949. Fachada oeste de la Iglesia de Assy
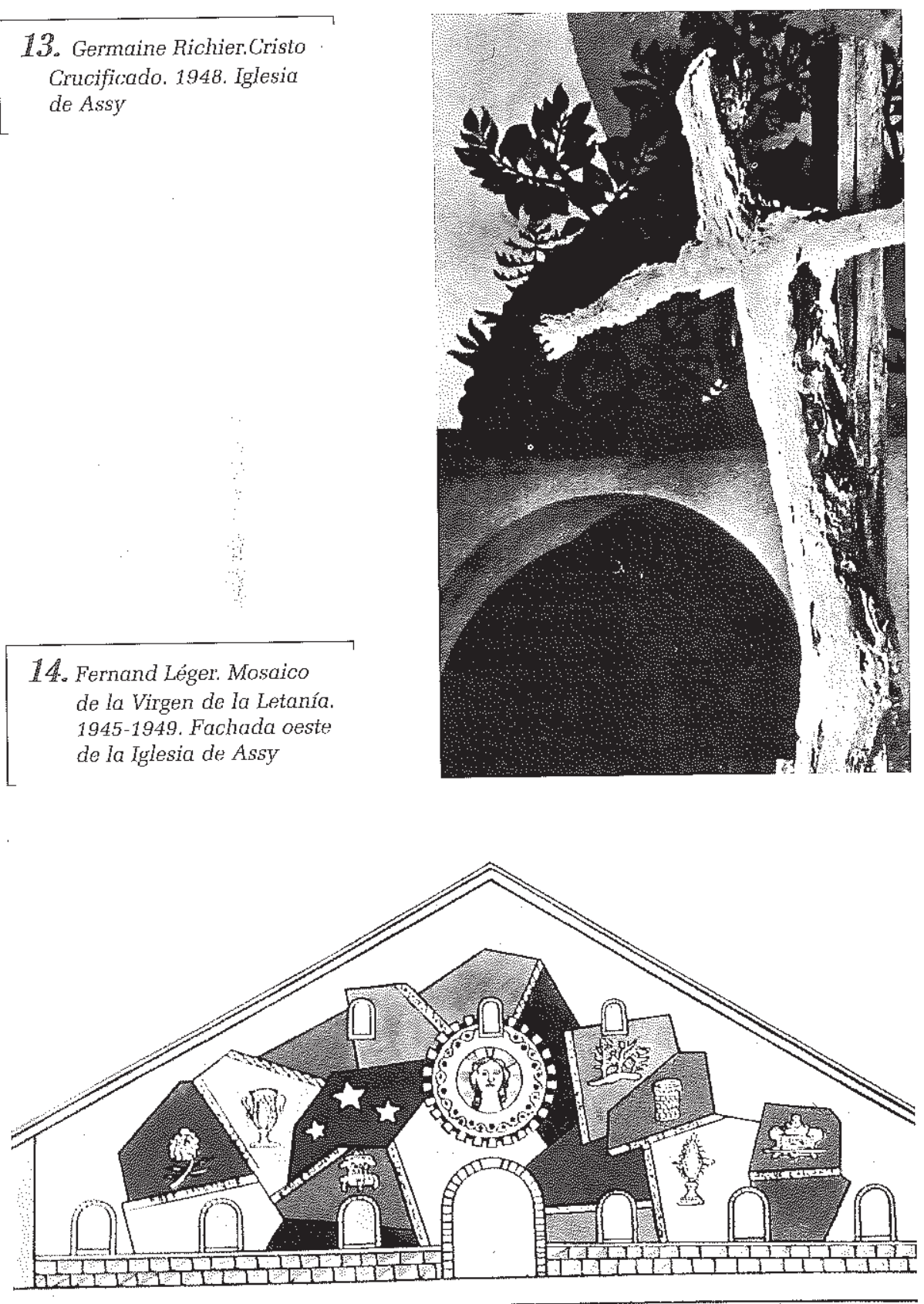


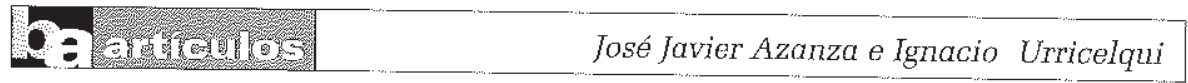

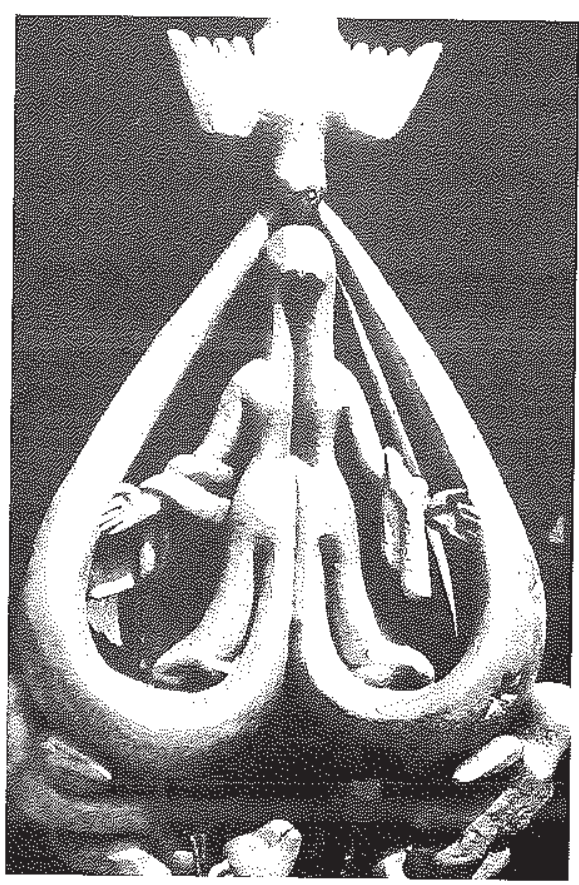

15. Jacques Lipchitz, Madonna. 1948. Iglesia de Assy

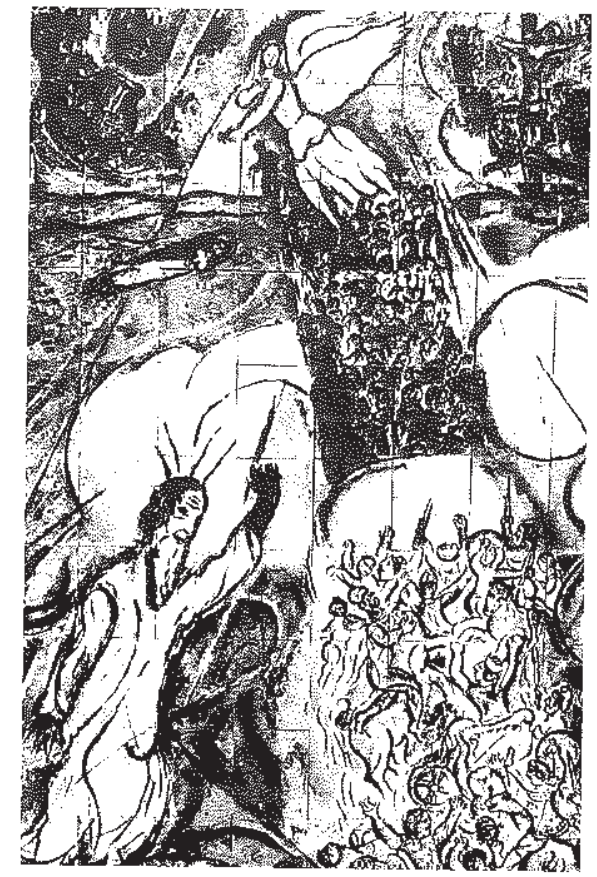

16. Marc Chagall, Mural cerámico de los israelitas atravesundo el Mar Rojo. 1948. Iglesia de Assy

conscientes y las opiniones filosóficas del artista, el acto de pintar era un acto religioso cuando estaba verdaderamente inspirado ${ }^{89}$. Pero con anterioridad a la consagración de la iglesia en 1950, parte de las obras, como el Cristo de Richier, fueron retiradas por las autoridades religiosas a los gritos de "Insulto" y "Sacrilegio", aduciendo que a estos artistas les falta la fe. Muchos otros artistas han tratado temas religiosos, pero mostrándose tan sólo respetuosos con un colectivo social y no proponiéndose hacer "arte sagrado". De esta manera, la querella sigue en pie: están luchando aquellos que piden, como condición esencial, la fe para iluminar el arte sacro, y los que por el contrario creen que el arte puede alcanzar por sí solo la verdad religiosa. ¿Cuál de las dos partes tiene razón? Interrogado años más tarde el escultor José López Furió sobre su arte religioso, respondía: Pienso que no se puede hacer lo que no se siente. Quizás sus palabras encierren la respuesta a dicha pregunta.

\footnotetext{
^9 GILOT, F., Picasso y Matisse. Una amistad entre artistas, Barcelona, Ediciones Destino, 1993,
pág. 190.
} 
De lo anteriormente expuesto parece deducirse que durante la primera mitad del siglo XX existe la firme creencia de que el arte religioso se encuentra en decadencia a consecuencia de la crisis total que, según muchos autores, afecta al hombre contemporáneo. Por otro lado, se defiende que el artista contemporáneo carece de los medios espirituales necesarios y de la capacidad de transmitir emoción para afrontar la elaboración de una obra sacra. Finalmente, encontramos la presencia de nuevas formas artísticas que bien por la figuración, bien por la abstracción, parecen querer ocupar el puesto tradicionalmente reservado a un tipo muy concreto de arte.

Admitidas estas ideas, cabe preguntarse por las soluciones aportadas para superar esta difícil situación. Algunos abogan por un regreso a modelos antiguos, si bien a juicio de otros esto supone retroceder y vivir del recuerdo. Por su parte, los hay que predican una vuelta del artista a las verdades de la fe, admitido mayoritariamente como el único camino para la digna realización de una obra religiosa. En este sentido, es claro el apoyo de Pío XII al arte y a los artistas para desarrollar.a través de la fe un arte digno al fin litúrgico que se propone. Respecto a la abstracción en el arte religioso, es una cuestión que queda más en el aire, ya que los hay que ven evidente tal posibilidad, frente a los que la creen totalmente fuera de lugar, e incluso la consideran indigna. Como puede comprobarse, la polémica resulta sumamente enriquecedora, aunque es muy difícil aportar soluciones, de manera que al final, tal y como apunta Manuel Graña desde El Debate, debieran aplicarse los principios de Santo Tomás, para quien toda obra de arte religioso debe tener plenitud de expresión, que diga con sobriedad aquello que se quiere decir; armonía de conjunto; equilibro del ritmo o dinamismo de los elementos plásticos; y claridad que deje ver la verdad completa.9.

\% GRAÑA, M., "Los artistas católicos de Londres", El Debate, 6 de abril de 1934. 
